\title{
Selenium in Biology: Facts and Medical Perspectives
}

\author{
J osef Köhrle ${ }^{1, *}$, Regina Brigelius-Flohé2, \\ August Böck ${ }^{3}$, Roland Gärtner ${ }^{4}$, Ortwin Meyer $^{5}$ \\ and Leopold Flohé \\ ${ }^{1}$ University of Würzburg, Division Molecular \\ Internal Medicine, Medizinische Poliklinik, \\ Röntgenring 11, D-97070 Würzburg, Germany \\ ${ }^{2}$ German Institute of Human Nutrition Potsdam, \\ Department Vitamins and Atherosclerosis, \\ Arthur-Scheunert-Allee 114 - 116, \\ D-14558 Bergholz-Rehbrücke, Germany \\ ${ }^{3}$ University of M unich, Institute of Microbiology, \\ M aria-Ward-Str. 1a, D-80638 München, Germany \\ ${ }^{4}$ University of Munich, Klinikum Innenstadt, Medizinische \\ Klinik, Ziemssenstr. 1, D-80336 München \\ ${ }^{5}$ University of Bayreuth, Institute of Microbiology, \\ Universitätsstr. 30, D-95440 Bayreuth, Germany \\ ${ }^{6}$ Technical University of B raunschweig, \\ Department of Biochemistry, Mascheroder Weg 1, \\ D-38124 Braunschweig, Germany \\ *Corresponding author
}

Several decades after the discovery of selenium as an essential trace element in vertebrates approximately $\mathbf{2 0}$ eukaryotic and more than $\mathbf{1 5}$ prokaryotic selenoproteins containing the $21^{\text {st }}$ proteinogenic amino acid, selenocysteine, have been identified, partially characterized or cloned from several species. Many of these proteins are involved in redox reactions with selenocysteine acting as an essential component of the catalytic cycle. Enzyme activities have been assigned to the glutathione peroxidase family, to the thioredoxin reductases, which were recently identified as selenoproteins, to the iodothyronine deiodinases, which metabolize thyroid hormones, and to the selenophosphate synthetase 2 , which is involved in selenoprotein biosynthesis. Prokaryotic selenoproteins catalyze redox reactions and formation of selenoethers in (stress-induced) metabolism and energy production of E. coli, of the clostridial cluster XI and of other prokaryotes. Apart from the specific and complex biosynthesis of selenocysteine, selenium also reversibly binds to proteins, is incorporated into selenomethionine in bacteria, yeast and higher plants, or posttranslationally modifies a catalytically essential cysteine residue of $\mathrm{CO}$ dehydrogenase. Expression of individual eukaryotic selenoproteins exhibits high tissue specificity, depends on selenium availability, in some cases is regulated by hormones, and if impaired contributes to several pathological conditions. Disturbance of selenoprotein expression or function is associated with deficiency syndromes (Keshan and Kashin-Beck disease), might contribute to tumorigenesis and atherosc lerosis, is altered in several bacterial and viral infections, and leads to infertility in male rodents.

Key words: Biosynthesis / Medical implications /

Redox regulation / Selenoproteins / Sperm maturation /

Thyroid function.

\section{Introduction: Some Historical Landmarks}

The element selenium, discovered in 1817 and named after the Greek goddess of the moon by Berzelius, gained biomedical interest after S chwarz and Foltz (1957) reported that it is an essential trace element for mammals. The link between nutritional science and enzymology was, however, established appreciably later when Flohé et al. (1973), intrigued by a preliminary report from Hoekstra's group (Rotruck et al., 1972), identified selenium as a stoichiometric, covalently bound component of glutathione peroxidase (GPx), an enzyme previously demonstrated to dominate mammalian hydroperoxide metabolism (Sies et al., 1972). Selenium proved to be present in this enzyme as a selenocysteine residue (Forstrom et al., 1978, Wendel et al., 1978) that is integrated into the amino acid chain (Günzler et al., 1984). The selenocysteine residue in GPx is responsible for the catalytic efficiency, as demonstrated by site- directed mutagenesis (Rocher et al., 1992), and the X-ray analysis performed by Epp et al. (1983) enabled a detailed understanding of the catalytic mechanism (Aumann et al., 1997; see also Figure 1A).

Starting in the mid-eighties, furtherselenoproteins were discovered that broadened the scope of selenium biochemistry from antioxidant defense to multiple aspects of mammalian metabolism. The metabolic activation (B ehne et al., 1990; Arthur et al., 1990; Davey et al., 1995), as well as degradation of thyroid hormones (Croteau et al., 1995), were shown to depend on selenium-containing deiodinases. Most surprisingly, selenium was also discovered in a well-documented enzyme of basic metabolic relevance, in thioredoxin reductase (Tamura and Stadtman, 1996). Finally, a homolog of GPx, the phospholipid hydroperoxide glutathione peroxidase (PHGPX) originally described by Ursini et al. (1982), proved to be involved in sperm maturation (Ursini et al., 1999). Further surprises may be anticipated from the growing number of mammalian selenoproteins. 
A
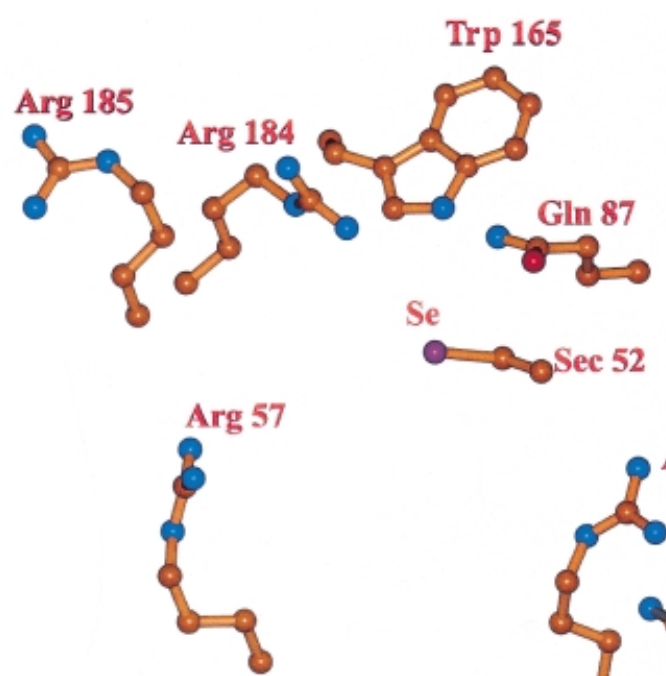

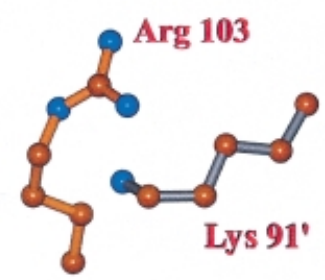

B

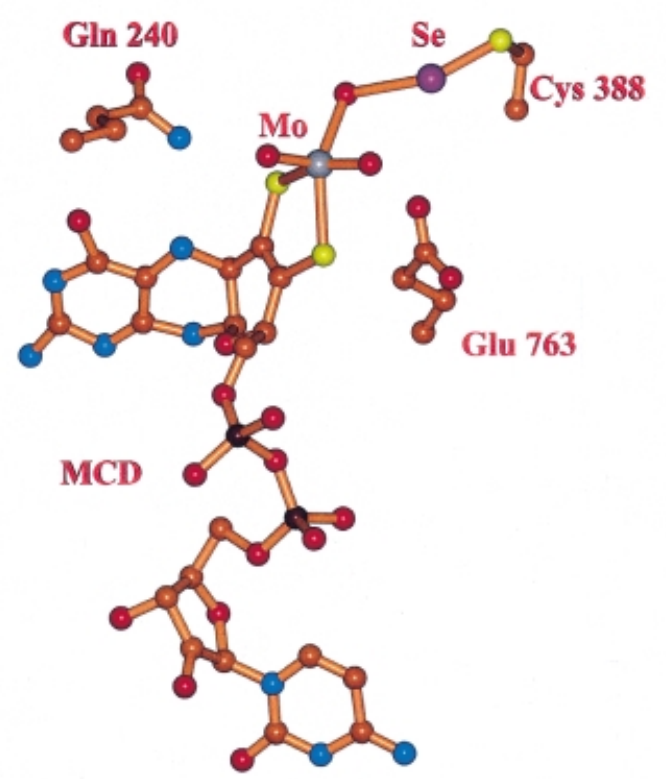

Fig. 1 Diversity of Reaction Centers of Selenoproteins.

(A) Active site of the classical mammalian glutathione peroxidase in its ground state, as modeled by Aumann et al. (1997) based on the $\mathrm{X}$-ray crystallographic analys is of Epp et al. (1983). The dissociated selenol function of selenocysteine (Sec 52) forms a catalytic triad with $\operatorname{Trp}^{165}$ and Glu ${ }^{87}$, as demonstrated for PHGPx by Maiorino et al. (1985). The basic residues Arg ${ }^{57,103,184,185}$ and Lys ${ }^{91}$ from the second subunit contribute to the optimum orientation of the reducing substrate GSH (Aumann et al., 1997).

(B) Reaction center of $\mathrm{CO}$ dehydrogenase from Oligotropha carboxidovorans according to Dobbeck et al. (1999). A molybdenum cofactor is buried in the center of the large subunit of $\mathrm{CO}$ dehydrogenase. The geometry of the first coordination sphere around the Mo ion forms a distorted square pyramid containing the dithiolene group of molybdopterin cytosine dinucleotide (MCD), two oxo- and one sulfido-group. The $\mathrm{CO}$ dehydrogenase preparations obtained from the bacteria contain active (sulfido-group present) and inactive enzyme (sulfido-group replaced by a hydroxy-group). The apical oxo-group is in hydrogen-bonding distance to the $\mathrm{N} 2$ of the conserved $\mathrm{GII}^{240}$. The other oxo-group is in hydrogen-bonding distance to the 01 of the conserved Glu ${ }^{763}$. The sequence Val-Ala-Tyr-Arg-Cys ${ }^{388}$-SerPhe-Arg at the active site contains the residue $\mathrm{Cys}^{388}$, which has been post-translationally modified to S-selanylcysteine. The S-selanylcysteine is catalytically essential and in a distance of $2.2 \AA$ to the sulfido-group. For further details see Dobbek et al. (1999).

Color codes: $C$, brown; $N$, blue; $O$, red; $S$, yellow; Se, magenta; $P$, dark red; grey backbone indicate second subunit of GPx. The figure was kindly prepared by H.-J . Hecht, GBF, B raunschweig, Germany.

The selenium biochemistry of mammalian systems was paralleled, in fact often preceded, by related discoveries in prokarya. Already in 1954 selenium was rated as a growth factor of certain bacteria (Pinsent, 1954). The first bacterial selenoproteins were described in 1973 (Andreesen and Ljungdahl, 1973; Turner and Stadtman 1973), and the growing diversity of enzymatic functions of such prokaryotic enzymes remains a valuable guide to unraveling the roles of less accessible mammalian enzymes. The present understanding of selenoprotein biosynthesis could not have been achieved without the aid of microbial genetics. The key observation, though, was made with a mouse gene: it obviously encoded a mouse GPx and displayed the stop codon TGA precisely at the position that should encode selenocysteine in the homologous bovine enzyme (Chambers et al., 1986) that had been previously completely sequenced by protein chemistry (Günzler et al., 1984). Within the same year Zinoni etal. (1986) established that TGA also encoded the selenocysteine discovered in bacterial formate dehydrogenase by J ones et al. (1979). Starting from these observations, the complex biosynthesis of selenoproteins was unraveled for bacteria in a transatlantic cooperation that remains inseparably associated with the names of Stadtman and Böck (Zinoni et al., 1986; Böck and Stadtman, 1988; Böck et al., 1991a,b). The attempts to understand eukaryotic selenoprotein biosynthesis has revealed homologies but also marked differences (B erry etal., 1991, 1993), and has not yet yielded a satisfying comprehensive view.

\section{Identified Selenoproteins}

Selenium usually exerts its influence on physiology as an integral component of proteins, into which it is incorporated in the form of selenocysteine (Cone et al., 1976; see below). Selenoproteins can be selectively labeled by ${ }^{75} \mathrm{Se}$ in selenium-deficient animals and autoradiographically visualized after electrophoretic separation (Behne et al., 1996). According to such experiments, the number of selenoproteins in mammals has been estimated to reach 30 - 50. Less than 20 of such bands have been characterized by sequence analysis up to now and an enzymatic function was assigned to more than ten of them. Among 
Table 1 Mammalian Selenoproteins.

\begin{tabular}{|c|c|}
\hline Selenoprotein (common abbreviations) & Key references \\
\hline \multicolumn{2}{|l|}{ Glutathione peroxidases (GPx) } \\
\hline Cytosolic or classical GPx (cGPx, GPx-1) & Mills 1957; Flohé et al., 1973 \\
\hline Phospholipid hydroperoxide GPx (PHGPx, GPx-4) & Ursini et al., 1982; B rigelius-Flohé et al., 1994 \\
\hline Plasma GPx (pGPx, GPx-3) & Takahashi et al., 1987 \\
\hline Gastrointestinal GPx (GI-GPx, GPx-GI, GPx-2) & Chu et al., 1993 \\
\hline \multicolumn{2}{|l|}{ lodothyronine deiodinases } \\
\hline 5'-deiodinase, type I (5’DI) & Behne et al., 1990; Arthur et al., 1990 \\
\hline 5'-deiodinase, type II (5'DII) & Davey et al., 1995 \\
\hline 5-deiodinase, type III (5-DIII) & Croteau et al., 1995 \\
\hline \multicolumn{2}{|l|}{ Thioredoxin reductases } \\
\hline Thioredoxin reductase (TrxR) & Tamura and Stadtman, 1996 \\
\hline Mitochondrial thioredoxin reductase (TrxR-2) & $\begin{array}{l}\text { Lee et al., 1999; Watabe et al., 1999; } \\
\text { Miranda-Vizuete et al., 1999; Gasdaska et al., } 1999\end{array}$ \\
\hline Thioredoxin reductase homologs (SelZf1; SelZf2) & Lescure et al., 1999 \\
\hline Selenophosphate synthetase- 2 & Guimaraes et al., 1996 \\
\hline \multicolumn{2}{|l|}{ Functionally undefined } \\
\hline 15 kDa selenoprotein of T cells & Gladyshev et al., 1998 \\
\hline Selenoprotein P 10 (SelP) & Motsenbocker and Tappel, 1984 \\
\hline Selenoprotein P 12 & Saijoh et al., 1995 \\
\hline Selenoprotein W (SelW) & Vendeland et al., 1995; Whanger et al., 1997 \\
\hline Selenoprotein R (SelR) & Kryukov et al., 1999 \\
\hline Selenoprotein T (SelT) & Kryukov et al., 1999 \\
\hline Selenoprotein X (SelX) & Lescure et al., 1999 \\
\hline Selenoprotein N (SeIN) & Lescure et al., 1999 \\
\hline
\end{tabular}

the identified and relatively well-characterized selenoproteins are four glutathione peroxidases (GPX), the cytosolic GPx (cGPx), the gastrointestinal GPx (GI-GPx), plasma GPx (pGPx) and phospholipid hydroperoxide GPx (PHG$P x)$, at least three thioredoxin reductases ( $\operatorname{TrxR})$, three deiodinases (D), the selenophosphate synthetase-2, the selenoprotein $\mathrm{P}$ (SeIP) present in plasma and a related variant in bovine brain (SelP 12), the selenoprotein $W$ in muscle, and some others of unknown function (Table 1 ).

In the majority of known mammalian selenoproteins, selenium occurs in the form of selenocysteine, which has proved to be essential for efficient catalysis (Maiorino et al., 1995; Gromer et al., 1998; Köhrle, 2000b; Lee et al., 2000). If selenocysteine is substituted by cysteine, the activity of the selenoenzymes falls by 2 to 3 orders of magnitude. Accordingly, the natural cysteine-containing PHGPX homolog from Plasmodium falciparum is approximately 1000 -fold less active than 'true' Se-PHG Px (Sztajer et al., 2000).

In prokarya, enzymes that were post-translationally modified with selenium were characterized. The carbon monoxide dehydrogenase, for instance, is an extremely complex molybdopterine-containing iron-sulphur-flavoprotein (Dobbek et al., 1999), in which a selanyl group is bound to a cysteine residue (Figure $1 B$ ). Such seleno- proteins have not yet been described in vertebrates. However, in prokarya the overwhelming number of selenoproteins contain selenocysteyl residues (Table 2 ). They comprise selenoproteins that are present in eukarya as sulfur homologs like the peroxiredoxins (Rhee et al., 1999; Flohé et al., 1999). Most prokaryotic selenoproteins, however, are unique and catalyze highly-varied processes that have not been discovered in eukarya. In the clostridial cluster XI (Kreimer and Andreesen, 1995; Wagner et al., 1999; Kabisch et al., 1999), selenoproteins are vital for energy production, particularly under stress, and appear to be important for additional metabolic performances and pathogenicity. A better understanding of such unique pathways in clinically relevant microorganisms might provide a rational basis for therapeutic intervention.

\section{Metabolic Function of Mammalian Selenoproteins}

Glutathione peroxidases are found in all mammalian tissues in which oxidative processes occur. By reduction of hydroperoxides to the corresponding alcohols, these enzymes can prevent the production of reactive oxygen radicals and thus may contribute to the protection of the 
Table 2 Selenoproteins in Prokaryotes ${ }^{a}$.

\begin{tabular}{|c|c|c|}
\hline Selenoprotein (gene name) & Function & References \\
\hline Glycine reductase & Formation of a selenoether & Arkowitz and Abeles, 1990 \\
\hline $\begin{array}{l}\text { Glycine/sarcosine/betaine reductase } \\
\text { Selenoprotein } \mathrm{A}(\mathrm{grdA})\end{array}$ & $\begin{array}{l}\text { Redox function, } \\
\text { transfer of a selenoether }\end{array}$ & Andreesen et al., 1999 \\
\hline Glycine reductase selenoprotein B (grdB) & Formation of a selenoether & Wagner et al., 1999 \\
\hline Sarcosine reductase selenoprotein B (grdF) & Formation of a selenoether & Andreesen et al., 1999 \\
\hline Betaine reductase selenoprotein B (grdH) & Formation of a selenoether & Andreesen et al., 1999 \\
\hline Proline reductase (prdB) & $\begin{array}{l}\text { Redox function, } \\
\text { formation of a selenoether }\end{array}$ & Kabisch et al., 1999 \\
\hline Heterodisulfide reductase (HdrA) & Redox function & Wilting et al., 1997 \\
\hline Seleno-peroxiredoxin (prxU) & Redox function (peroxidase) & Andreesen et al., 1999 \\
\hline Putative redox active selenoprotein (prpU) & Redox function & Andreesen et al., 1999 \\
\hline Formate dehydrogenase (fdhF) & Hydrogen donor & Boyington et al., 1997 \\
\hline $\begin{array}{l}\text { Formylmethanofuran dehydrogenase } \\
\text { (fwuB) }\end{array}$ & Redoxfunction & Vorholt et al., 1997 \\
\hline NiFeSe-hydrogenase (hydV) & Hydrogen donor & Garcin et al., 1999 \\
\hline $\begin{array}{l}\mathrm{F}_{420} \text { non-reducing hydrogenase } \\
\text { (vhuU, vhuD) }\end{array}$ & Redox function & Pfeiffer et al., 1998 \\
\hline $\mathrm{F}_{420}$ reducing hydrogenase (fruA) & Redox function & Wilting et al., 1997 \\
\hline Selenophosphate synthetase (selD) & $\begin{array}{l}\text { Formation of key metabolite } \\
\text { for selenop rotein synthesis }\end{array}$ & Lacourciere and Stadtman, 1999 \\
\hline CO dehydrogenase (coxL) & $\begin{array}{l}\text { Formation of a carbon oxide } \\
\text { selenide }\end{array}$ & Dobbek et al., 1999 \\
\hline Nicotinic acid hydroxylase & Unknown & Gladyshev et al., 1996 \\
\hline Xanthine dehydrogenase & Unknown & Schräder et al., 1999 \\
\hline
\end{tabular}

${ }^{\text {a }}$ Adapted from Flohé et al. (2000).

organism's macromolecules and biomembranes against oxidation (Sies etal., 1972; Flohé, 1989; Ursini etal., 1995). The role of the cytoplasmic GPx as an 'emergency enzyme' to fight oxidative stress was verified by reverse genetics (Ho et al., 1997; Cheng et al., 1998; de Haan et al., 1998; Fu et al., 1999; J aeschke et al., 1999) and, in this role, CGPx cannot be substituted by any of the other selenoproteins. Glutathione peroxidases, in particular the less ubiquitously distributed isozymes, are engaged in redox regulation of many metabolic processes (BrigeliusFlohé, 1999) and appear to be involved in peroxinitrite scavenging (Sies et al., 1997). PHG Px may, e. g., regulate the biosynthesis of leukotrienes, thromboxanes and prostaglandins and thus modulate inflammatory processes (Smith and Lands, 1972; Haurand and Flohé, 1988; Schnurr et al., 1996; Weitzel and Wendel, 1993; Imai et al., 1998). Glutathione peroxidases, in particular PHGPX, have further been shown to dampen cytokine-induced transcriptional gene activation (Brigelius-Flohé et al., 1997), e. g. by inhibiting phosphorylation of $I_{\kappa} B$ (KretzRemy et al., 1996).

All of the three deiodinase isoenzymes identified up to now appear to contain selenocysteine (Figure 2). These enzymes catalyze the activation of the prohormone thyroxine (T4), which is secreted by the thyroid, to the active thyroid hormone 3,3',5-triiodothyronine (T3) (type I and type II 5'-deiodinase) or the deiodination of T4 and T3 to metabolites (type III 5-deiodinase) that are not hormonally active. These three isozymes are encoded by different genes and show distinct specificities, tissue- and development-specific expression patterns and regulation. Essentially they control the local availability and concentration of the highly active thyroid hormone T3 (reviewed in Köhrle, 1999a, b, 2000a,b).

In contrast to prokaryotic homologs, thioredoxin reductase of mammals was identified as a selenoprotein (Tamura and Stadtman, 1996). It needs selenocysteine as the penultimate amino acid residue for its appropriate enzymatic function (Marcocci et al., 1997; Gromer et al., 1998; Lee et al., 2000; Gorlatov and Stadtman, 2000). Recently, two more tissue-specifically expressed isoenzymes were also identified as selenoproteins (Gasdaska et al., 1999; Lee et al., 1999; Watabe et al., 1999) and related proteins were identified by 'in silico' cloning (Lescure et al., 1999). Various natural and synthetic compounds, apart from disulfide groups in peptides and proteins, can be reduced by TrxR (Holmgren and Björnstedt, 1995; Björnstedt et al., 1995). The natural substrate of TrxR, thioredoxin (Trx), is a central regulator of the cellular redox status (Follmann and Häberlein, 1995). It is, e. g., required for the redox-regulated function of transcription factors and hormonally-regulated nuclear receptors. Furthermore, ribonucleotide reductase needs reduced Trx for the production of deoxynucleotides. Thus, TrxR enables a basic metabolic process and regulates multiple metabolic events in eukaryotic cells (Hayashi et al., 1993; Björnstedt et al., 1997; Makino et al., 1999; Holmgren, 2000). Likely, it is the pivotal role of selenium in TrxR that explains why a knock-out of the seleno- 


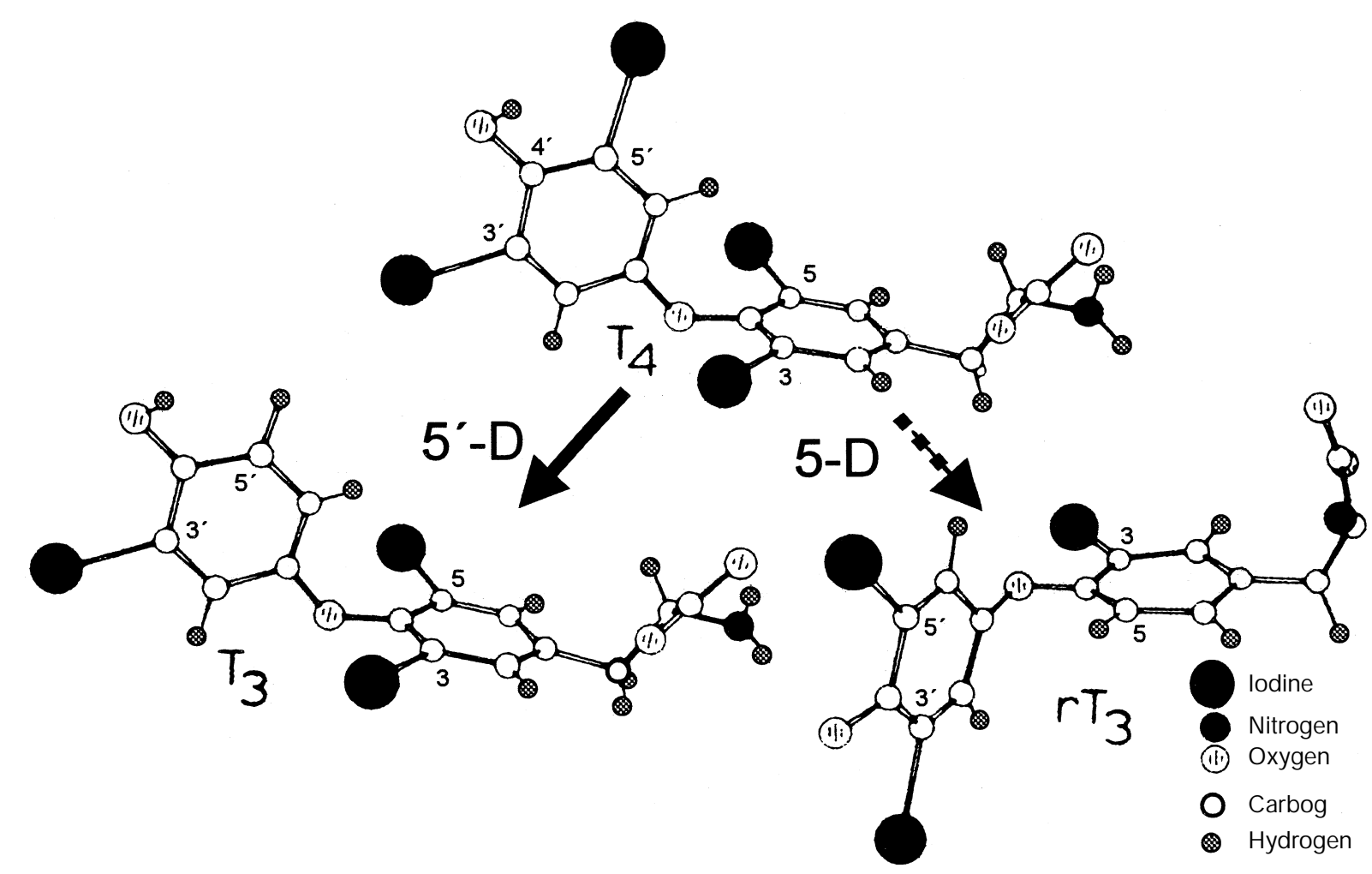

Fig. 2 Metabolism of Thyroid Hormone by 5' and 5-Deiodinases.

Reductive $5^{\prime}$-(phenolic ring) deiodination of the prohormone L-thyroxine $\left(3,3^{\prime}, 5,5^{\prime}\right.$-tetraiodo-L-thyronine, $\left.T_{4}\right)$ to thyromimetically active 3,3'-5-triiodo-L-thyronine $\left(T_{3}\right)$ is catalyzed by the two deiodinase selenoenzymes, type I and type II $5^{\prime}$-deiodinase $\left(\longrightarrow 5^{\prime} D\right)$. Type III 5-deiodinase (5-D - - - $)$ ) removes iodide in 5-position from the tyrosyl ring of $\mathrm{T}_{4}$ and forms thyromimetically inactive $3,3^{\prime}, 5^{\prime}$-triiodo-Lthyronine (reverse $\mathrm{T}_{3}, \mathrm{rT}_{3}$ ). Figure 2 illustrates the conformational aspects of thyroid hormones and the bulky iodine atoms (black) of the non-planar diphenylether aromatic ring system (modified from Cody et al., 1986). Whereas T4 and T3 occupy a skewed conformation, the inactive metabolite rT3, lacking the iodine atom in the 5-position, has an antiskewed orientation of the two phenolic rings. The physiological cofactor(s) of these deiodinase selenoenzymes is (are) unknown.

cysteyl-tR NA gene is lethal in mice (B ösl et al., 1997), since targeted disruption of the thioredoxin gene proved to be equally lethal (Matsui et al., 1996).

Approximately $60-70 \%$ of the plasma selenium is bound in the selenoprotein $\mathrm{P}$. The function of this protein is not yet clear. It is assumed to be an extracellular antioxidative protein which contributes to the decomposition of peroxinitrite (Arteel et al., 1998; 1999) or might exhibit some in vitro peroxidase activity (Sies et al., 1999) like many natural and synthetic selenocysteine-containing proteins (Haring and Schreier, 1999). However, it could equally well bind heavy metals (Burk and Hill, 1994). The role of the selenoprotein $\mathrm{P}$ as a transport protein of selenium in plasma has meanwhile been questioned, because selenocysteine could only be released by destroying the protein (Burk and Hill, 1994). Selenoprotein $P$ is presumed to exert its antioxidative effect particularly in the vascular system, where it is bound to endothelial cells with high affinity (Hill and Burk, 1997), probably via its histidine-rich domains as shown by in vitro interaction with heparin (Arteel et al., 2000). The inhibition of the activity of the human selenoprotein $\mathrm{P}$ promoter and the protein expression through pro-inflammatory cytokines and TGF $\beta$ in liver cells characterizes selenoprotein $P$ as a negative acute phase protein (Dreher et al., 1997, Mostert et al., 1999).
Recently, selenoprotein $\mathrm{P}$ has further been reported to promote neuron survival in vitro (Yan and Barrett, 1998).

\section{The Biosynthesis of Selenoproteins}

The biosynthesis of selenoproteins in prokaryotes has been largely clarified (Böck, 2000; Figure 3). Related studies were mainly conducted with formate dehydrogenase in E. coli, which also contains selenium as a selenocysteine residue integrated in the peptide chain. The insertion of the selenocysteine is encoded by the triplet TGA, which usually functions as a stop codon (Zinoni et al., 1986; Böck and Stadtman, 1988; Böck etal., 1991a). Recoding of TGA as a selenocysteine codon requires an mRNA secondary structure called SECIS (for selenocysteine-insertion sequence), which, in bacteria, is localized immediately downstream of the UGA codon. This secondary structure is recognized by a special translation factor, SelB (Baron et al., 1993), which directs a special tRNA ${ }^{\text {(Ser)Sec }}$, encoded by the SelC gene, to the ribosome, where the latter enables the incorporation of selenocysteine by means of a UGA anticodon (Leinfelder et al., 1988; Forchhammer et al., 1991). The selenocystyl-loaded tR NA ${ }^{(\mathrm{Ser}) \mathrm{Sec}}$ is synthesized from a seryl-loaded tRNA ${ }^{(\mathrm{Ser}) S e c}$ by means of selenophos- 
A) Formation of the selendonor, selenophosphate

$$
\mathrm{ATP}+\mathrm{H}_{2} \mathrm{Se} \stackrel{\text { SELD }}{\longrightarrow} \mathrm{H}_{3} \mathrm{PO}_{3} \mathrm{Se}
$$

B) Formation of selenocysteine-loaded tRNA(ser)sec

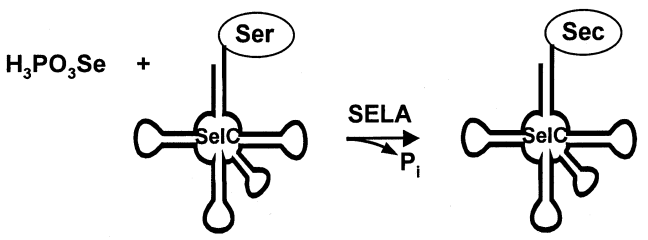

C) Formation of the putative complex for the cotranslational incorporation of selenocysteine

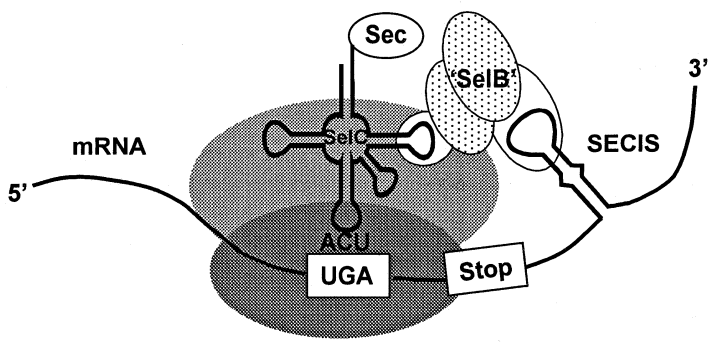

Fig. 3 Model of Selenocysteine Incorporation in Eukarya. Decoding of the UGA codon as selenocysteine and its subsequent incorporation requires a complex multicomponent system and several reactions. These include: $(A)$ the formation of the selenium donor, selenophosphate, from ATP and selenide, catalyzed by the selenophosphate synthetase-2 (SELD), which is a selenoenzyme by itself; (B) a specific tRNA, called tRNA ${ }^{(\text {Ser)Sec }}$ or SelC, which is first loaded with serine and then converted into selenocysteine ( $\mathrm{Sec}$ ) by selenocysteine synthase (SELA) using selenophosphate as selenium source; (C) a putative translation complex in analogy to the established complex in prokarya. The mRNA forms a characteristic secondary structure in the 3' nontranslated region, the selenocysteine incorporating sequence (SECIS). The selenocysteine-loaded tRNA ${ }^{(\mathrm{Ser}) \mathrm{Sec}}$ is transferred to the ribosome $A$ site and recognizes the UGA codon by its anticodon ACU. The complex is stabilized via the interaction of putative SECIS-binding proteins ('SeIB') with the SECIS and the tRNA. These components of the translational complex remain to be identified.

phate (Leinfelder et al., 1990), which is generated from $\mathrm{H}_{2} \mathrm{Se}$ and ATP (Lacourciere, 1999; Lacourciere and Stadtman, 1999).

The eukaryotic system of selenoprotein synthesis appears to be homologous in part (Figure 3 ). The selenocysteine codon is TGA (UGA) again; the tRNA ${ }^{\text {(Ser)Sec }}$ (Lee et al., 1989) and the selenophosphate synthetase (Low et al., 1995; Guimaraes et al., 1996; Lacourciere and Stadtman, 1999) are closely related. The essential difference of the eukaryotic selenocysteine biosynthesis system consists in the position of the SECIS element. In eukarya, it is located in the $3^{\prime}$ nontranslated region and thus decoding from an appreciable distance is necessary (Berry et al., 1993; Low and Berry, 1996). In this respect the archaeal seleno- protein biosynthesis is more similar to the eukaryotic system than to the bacterial system (Wilting et al., 1997). Considering the similarity of the systems, a SelB-orthologous translation factor is also postulated for eukarya, which should have affinity to both SECIS and TRNA ${ }^{\text {sec }}$ (Flohé et al., 1997), and should control the correct decoding of the distant UGA codon by competing with the termination factor (Nasim etal., 2000). Up to now, the eukaryotic SelBortholog could not yet be id entified. Using gel shift experiments, various proteins that bind to eukaryotic SECIS structures were detected. The bands, however, differ in molecular masses (from 48 - $120 \mathrm{kDa}$ ) and their affinities to SECIS elements of a given selenoprotein MRNA could usually not be compared to that of other SECIS elements (Shen et al., 1995, 1998; Yamada, 1995; Hubert et al., 1996; Lesoon et al., 1997). A protein of $120 \mathrm{kDa}$ was reported to be required for eukaryotic selenoprotein biosynthesis (Copeland et al., 2000). It does not, however, display any homology with bacterial SelB and appeared to be only part of a larger complex. Most of these SelB candidates can therefore equally be considered as nucleic acid-binding proteins that regulate, e.g. tissue-specific expression of certain selenoproteins or mRNA stability and the functions of bacterial SelB, i. e. binding of the SECIS element and tRNA $^{(\mathrm{Ser}) \mathrm{Sec}}$, as well as selenocysteine incorporation, might be exerted by two (or more) different proteins in archeae and mammalia (Rother et al., 2000).

\section{Regulation of Selenoprotein Expression}

\section{Tissue-Specific Expression}

The more common selenoproteins display an expression pattern that reflects the metabolic activity of the tissue, whereas others are more selectively distributed.

Type I 5'-deiodinase is found primarily in thyroid, liver, kidney and pituitary, type II 5'-deiodinase in brown fat tissue of rodents, in placenta, thyroid, pituitary, and in the central nervous system, type III 5-deiodinase in skin, placenta and also in the central nervous system (Köhrle, $2000 \mathrm{~b})$. The testicle is the tissue containing the highest amount of PHGPx (Maiorino et al., 1998). In Schistosoma mansoni, $P H G P x$ is found in the female genitals (Maiorino et al., 1996). GI-GPx is expressed only in the gastrointestinal tract (Chu et al., 1993, Mörk et al., 1998; Wingler and B rigelius-Flohé, 2000), whereas pGPx is secreted and preferentially formed at metabolic surfaces (proximal tubulus of the kidney, intestinal epithelium, skin, lung, epididymis, vas deferens, chorioidal plexus; Brigelius-Flohé, 1999). The extracellular selenoprotein $P$ displays a similar expression pattern but is highly expressed in liver and, surp risingly, also in testicular Leydig cells and the P urkinje layer of the cerebellum (Steinert et al., 1998). Among the selenoproteins, which are not yet defined functionally or structurally, selenoprotein $\mathrm{W}$ is found in heart and skeletal muscle, other poorly characterized selenoproteins in testis, prostate and pancreas (B ehne et al., 1997). 
The sometimes unusual expression pattern certainly points to highly-specialized roles. In none of the cases has the molecular basis for tissue-specific expression so far been elucidated and, apart from PHGPx and the deiodinases (see below), the tissue-specific biological role of the selenoproteins remains obscure.

\section{Hormone-Dependent Regulation}

In fetal osteoblast-like cells ( $\mathrm{hFOB}$ ), human thioredoxin reductase is rapidly induced, like an immediate-early gene, through 1,25-dihydroxy vitamin D3, certain cytokines and growth factors; here also the selenium status modulates the expression of TrxR (S chütze et al., 1998a, b). The three deiodinase isoenzymes are regulated by thyroid hormones, retinoids, sexual hormones, gluco- and corticosteroids and a series of growth factors and cytokines, as verified by promoter studies for individual deiodinase isoenzymes ( akobs et al., 1997; Schmutzler et al., 1998, for an overview see Köhrle, 2000b).

Hormone-dependent expression of PHGPx, which had been assumed to be mediated by putative hormoneresponsive elements in the promoter or in the introns (Brigelius-Flohé et al., 1994), could not be verified by reporter gene constructs. PHGPx rather is preferentially expressed in round spermatids. These cell's development in turn depends on testosterone (Maiorino et al., 1998). The androgen-dependent expression of pGPx in epididymis might be based on the same principle of hormone-mediated growth and differentiation of the producing cell type (Schwaab et al., 1998).

\section{Regulation by Oxidative Stress}

An induction of GPx genes by oxidative stress was often postulated but has never been convincingly demonstrated in vivo. The induction of cGPx through an oxygen-responsive element has only been described in vitro (Cowan et al., 1993; for a review see Flohé et al., 1997).

\section{Selenium-Dependent Regulation}

Biosynthesis of selenoproteins, of course, depends on the bioavailable selenium. Their biosynthesis, however, follows a strict hierarchy in the case of limited selenium supply (Burk and Hill, 1993; Sunde, 1994; Gross et al., 1995; Flohé et al., 1997). Even within the family of glutathione peroxidases there are enormous differences in the expression in response to selenium (B rigelius-Flohé, 1999). In all examined cases the PHGPx activity in selenium deficiency was stable for a long time, whereas the activity of cGPx declined quickly and substantially (Lei et al., 1995). This loss of activity upon selenium deprivation is not only caused by reduced protein synthesis, but also by enhanced degradation of the pertinent mRNA. The mRNA stability of the CGPx is the lowest, that of the PHGPx is relatively unchanged and reduced only under severe selenium deficiency. That of GI-GPx is extremely high. The mRNA even increases under poor selenium provision (Wingler et al., 1999). The reasons for this phenomenon are not clear at all. It is likely that the mR NA stability is regulated by selenium-responsive RNA-binding proteins in an analogous way as has been demonstrated for mRNA of proteins involved in iron metabolism (Hentze, 1991). It has not yet been examined in detail whether mRNA stability responds to selenium in a tissue-specific manner.

\section{Medical Implications}

The characteristics of selenium deficiency, but also of selenium toxicity, are largely known from epidemiological studies. At present, a daily intake of $70 \mu \mathrm{g}$ for adults is considered normal, while daily intakes below $20 \mu \mathrm{g}$ are rated as insufficient. The toxicity limit is estimated at $800 \mu \mathrm{g}$ per day (Bähr etal., 1999).

Comprehensive analyses of selenium deficiency in livestock production and agriculture were conducted in the US, New Zealand and other regions with varying selenium supply, as reviewed extensively by the National Research Council (1983) of the United States. As a consequence, selenium supplementation of animal food or the use of mineral fertilizers has become routine in many seleniumdeficient countries, although the basic biochemical processes causing the deficiency symptoms remain to be worked out. Human selenium supply relies on such animal-mediated enrichment of the food chain in many regions of the world, where selenium, like iodine, has been eluted from agriculturally-used soils and earth surfaces and is no longer supplied to the food chain via assimilation by plants.

\section{Manifest Selenium Deficiency}

While typical selenium deficiency synd romes of livestock, like white muscle disease in cattle, mulberry heart disease in pig, and exsudative diathesis in poultry, have been recognized in many countries, manifest selenium deficiency is commonly not a problem for humans living in developed countries, where people have access to varied food derived from diverse sources. Human diseases unambiguously attributed to, or associated with, selenium deficiency have been reported to occur only in remote rural areas with extreme selenium deficiency.

In a cooperation between Chinese and American groups, the pathophysiology of the exemplary Chinese selenium deficiency syndrome, Keshan disease, was largely clarified: against the background of a selenium deficiency, coxsackie viruses become virulent. This etiology of Keshan disease has recently been corroborated by compelling animal experiments. In both selenium-deficient and cGPx(-/-) mice, avirulent Coxsackie strains mutated into virulent ones (Beck et al., 1998). Selenium deficiency, thus, is a necessary but not a sufficient condition to cause disease manifestation.

Detailed concepts for the pathogenesis of the myxoedematous cretinism have been developed from epidemiological and intervention studies by Dumont's team in Brussels in cooperation with Central African and Asian 
teams. The resulting hypotheses are now being tested in animal experiments. This disease occurs in the case of a serious simultaneous selenium and iodine deficiency, whereas iodine deficiency alone leads to a neurological type of cretinism (Dumont et al., 1994; Köhrle 1999a). Whether the Kashin Beck osteoarthropathy is also caused by selenium deficiency or combined selenium and iodine deficiency is still the topic of scientific controversy. In any event, further pathogenic factors, e.g. mycotoxins, appear to contribute to this peculiar syndrome ( $\mathrm{Ge}$ and Young, 1993; M oreno-Reyes et al., 1998).

\section{Selenium and Tumor Incidence}

The relationship between selenium supply and cancer incidence is supported by epidemiological surveys, and cohort and case control studies, as well as by retrospective and prospective prevention or intervention studies (National Research Council, 1983). Different approaches from several regions (e.g. China, USA, Scandinavia) almost unanimously demonstrated low selenium intake to be associated with a higher incidence of mammary, thyroid, prostate, lung and colorectal carcinoma (for recent overviews see Combs etal., 1997; Combs and Gray, 1998; Knekt et al., 1998). Animal experiments on initiation, promotion and proliferation of tumors tended to support a beneficial effect of selenium. In animal experiments, however, individual selenium compounds differed in their efficacy (Ip and Ganther, 1990; Ip, 1998). The protective effect of selenium is not readily explained in terms of prevention of oxidative DNA damage, since, as a rule, higher dosages of selenium than those optimizing peroxide metabolism are required (Combs et al., 1997; Combs and Gray, 1998; Ganther, 1999). Accordingly, topical discussions presume a direct antiproliferative effect of pharmacological selenium concentrations, be it due to enhancement of apoptosis by excess selenium supply or to distinct inhibition of proliferation-enabling enzymatic processes by certain selenium metabolites (Ganther, 1999).

A pivotal prospective, placebo-controlled, doubleblind study conducted with more than 1100 patients over 4.5 years on average and a selenium supplementation of $200 \mu \mathrm{g} / \mathrm{d}$ in the form of selenium-enriched yeast remained ambiguous in failing the main endpoint, i. e. lowering the recurrence of non-melanoma skin cancer, but surprised in meeting secondary endpoints beyond expectations: total cancer incidence and cancer mortality were significantly lowered by supplementation. Particularly the incidence of colorectal, pancreatic and lung tumors decreased during the intervention and the 6.5-year follow up-period in the selenium-supplemented group (Clark et al., 1996). To comply with biometric rules, however, the observations have to be verified in dedicated examinations.

\section{Selenium and Intensive Care Medicine}

Critically ill patients, above all those with systemic inflammatory response syndrome (SIRS), have lower serum selenium levels and GPx activity already when they are ad- mitted to intensive care units (Hawker et al., 1990; Gärtner et al., 1997). In SIRS patients, the abundant $\mathrm{H}_{2} \mathrm{O}_{2}$ formation necessitates adequate protection by glutathione peroxidases (Prabha et al., 1991). Low serum selenium levels correlate with the low GPx activity and are almost consistently found during the hyperdynamic septic phase of shock, after surgery, or in patients with liver diseases (Robinson et al., 1992). Also, serum selenium levels correlate inversely with mortality (Forceville et al., 1998). The reason is still not clear. Selenium-deficient nutrition is discussed as a predisposing factor for SIRS (Richard et al., 1991; Ringstad et al., 1993). But also a rapid redistribution of selenium in the body or an excretion through the kidney at the beginning of the disease has been supposed, but could not yet be analytically verified (Forceville et al., 1998). During longer parenteral nutrition and continuation of the disease the selenium level further decreases (Hawker et al., 1990; Sando et al., 1992). It is equally unclearhow a selenium supplementation might interfere with the septic syndrome. Normalization of peroxide metabolism is most frequently discussed. But a mechanistically unclear improvement of the immune response that is observed upon selenium supplementation (McKenzie et al., 1998), comprising inter alia enhanced activity of natural killer cells (Dimitrov et al., 1986), might be of particular relevance in the late phases of SIRS.

First pilotstudies have addressed the effect of selenium on septic diseases with promising results (Gärtner et al., 1997; Zimmermann et al., 1997; Angstwurm et al., 1999). In these conditions, the usual parenteral nutrition, which contains low dosages of selenium ( $35 \mu \mathrm{g} /$ day), neither leads to a normalization of serum selenium levels nor to an increase of GPx activity. Based on the preliminary data, controlled prospective studies examining the efficiency of selenium at different dosages in an adequate number of patients appear mandatory, because SIRS still has one of the highest mortality rates ( $40 \%$ on average) among the acute diseases.

\section{Selenium and Thyroid Function}

The human thyroid contains a high amount of selenium because it produces $\mathrm{H}_{2} \mathrm{O}_{2}$ for oxidative thyroid hormone synthesis and has to protect itself from oxidative damage by the expression of selenoperoxidases. Moreover, it needs selenium for activating the prohormones of $\mathrm{T} 4$ to T3 catalyzed through the 5'-deiodinases. As mentioned above, serious selenium deficiency combined with iodine deficiency leads to a myxedematous type of cretinism. In iodine deficiency, the production of $\mathrm{H}_{2} \mathrm{O}_{2}$ is stimulated by pituitary thyrotropin (Dumont et al., 1994). In this condition, the thyroid is postnatally damaged and becomes fibrotic under the influence of TGF $\beta$ (Contempre et al., 1996). But there are also hints that the selenium status influences the progress of auto-immune diseases of the thyroid ( $1 / 6$ of all women have thyroid auto-antibodies) by unclear mechanisms (Schmidtetal., 1998; Köhrle, 1999a). Also, lower selenium concentrations can be found in thy- 
roid tumor tissue (Köhrle, 1999a). In a large-scale Norwegian study, a significantly higher incidence of thyroid tumors correlated with prediagnostical low selenium levels (Glattre et al., 1989). The role of the individual selenoproteins in pathologically altered thyroid tissue is, however, as unclear as their contribution to auto-immune diseases and tumor development. Neither is it evident whether there is a direct link between the low selenium status in critically ill patients (e.g. SIRS) and the simultaneously observed low T3-production due to inefficiently expressed hepatic selenoprotein type I 5' deiodinase in the 'Low-T3Syndrome' (Köhrle et al., 2000b).

\section{Selenium and Male Fertility}

The necessity of adequate selenium provision for male fertility is known particularly from veterinary medic ine (see National Research Council, 1983, and Flohé, 1989 for older literature). Yet the precise role of selenium in male fertility remained an enigma for decades. In sperm, selenium is largely associated with the keratin-like material that embeds the helix of mitochondria in the midpiece of spermatozoa. A protein derived from this so-called mitochondrial capsule was reported to contain selenium and accordingly termed 'mitochondrial capsule selenoprotein (MCS)' (Pallini and Bacci 1979; Calvin et al., 1981). The pertinent genes of rats and mice, however, did not contain any TGA codons within the translated regions (Adham et al., 1996; Cataldo et al., 1996). Accordingly, MCS could no longer be considered the selenoprotein essential to sperm function. More recent studies showed that PHGPX is abundantly expressed in spermatogenic cells (M aiorino et al., 1998, 1999; Mizuno et al., 2000) but exists as an enzymatically-inactive structural protein in mature sperm, where it contributes to the formation of the mitochondrial capsule (Ursini et al., 1999). In spermatozoa, PHGPx thus replaces $\mathrm{MCS}$, which had mistakenly been considered a selenoprotein. Because the morphological defects of sperm under selenium deficiency primarily affect the mitochondrial capsule, reduced fertility can conceivably be explained by insufficient PHGPx synthesis. The relevance of further selenoproteins that are specifically expressed in the male genitalia (Behne et al., 1997) has yet to be clarified.

\section{Selenium and Atherogenesis}

Fatty acid and cholesterol ester hydroperoxides, as present in oxidized LDL (oxLDL), are believed to initiate atherogenesis (Steinberg, 1997). In atherosclerotic lesions, hydroperoxides as well as the 15-lipoxygenase were found (Ylä-Herttuala, 1991), and lipid hydroperoxides can induce adhesion molecules in cultivated endothelium cells (Friedrichs et al., 1999). Both oxLDL-induced foam cell formation and smooth muscle cell proliferation and hydroperoxide-induced presentation of adhesion molecules are considered to synergize in the initiation of atherogenesis.

A prophylactic role of selenium in the prevention of cardiovascular disturbances was observed in epidemiologi- cal studies (National Research Council, 1983; Salonen, 1987). In view of the oxidative processes implicated in early atherogenesis, the selenium effect is tentatively attributed to the optimization of glutathione peroxidase activities. Possible candidates would particularly be the $\mathrm{pGPx}$ as an extracellular enzyme and PHGPx, which efficiently reduces hydroperoxides in oxidized LDL. This seemingly straightforward hypothesis, however, suffers from at least two inconsistencies: pGPx lacks a sufficient supply of reducing capacity in the extracellular compartment (Brigelius-Flohé, 1999) and does not have the optimum specificity (Yamamoto and Takahashi, 1993), PHGPxdoes display the optimum specificity to reduce all kinds of hydroperoxy groups in oxLDL (Ursini etal., 1982, 1995) but is not present extracellularly, where LDL is oxidized, and does not readily decline in moderate selenium deficiency. Clearly, the link between selenium and atherogenesis, if real, has still to be identified. It is likely that the redox regulation of lipid mediator synthesis and cytokine-dependent signaling is more relevant to the initiation of atherogenesis than the mere antioxidant potential of selenoperoxidases (Brigelius-Flohé, 1999).

\section{Conclusions}

The exponential progress in selenium biochemistry over the last two decades led to the identification, cloning and functional characterization of more than a dozen selenoenzymes with widely varied catalytic potential, and the key events of selenoprotein biosynthesis have been elucidated. This review is, however, not primarily meant to celebrate these achievements, it rather aims at underscoring that most of the roles of the essential trace element in biology still remain as obscure as they have been for most of the last century. This is because the trace element typically hides in 'trace enzymes'. In fact, the present state of the art could not have been achieved without advanced molecular biology techniques and most sophisticated physicochemistry.

For a long time, the selenium biochemistry was misinterpreted as the search for biological curiosities that might detract serious scientists from central biological problems. This view can no longer be maintained: as an integral moiety of the thioredoxin reductases it is relevant to basic steps of nucleic acid synthesis; it proved to be essential for male fertility in mammals; and the knock-out of the selenocystyl-tRNA gene in mice was lethal (Bösl et al., 1997) and thus revealed that at least one of the selenoproteins must be indispensable for mammalian life in general.

Most of the known selenoproteins were detected in either bacteria and archaea or in mammals, but selenoproteins are definitely also present in lower eukarya (Maiorino et al., 1996). Little is known about the role of selenium in the remaining living kingdom. Plants appear not to depend on selenoenzymes, yet they contain numerous low molecular weight selenocompounds of nutritional, 
pharmacological, and toxicological interest (Läuchli, 1993; Neuhierl et al., 1999). Together with bacteria, which may also 'dissimilate' bioavailable selenite to elementary selenium (Garbisu et al., 1995), plants, by assimilation of inorganic selenium, certainly contribute to the maintenance of the geo-ecological selenium homeostasis that is equally important for livestock and human health (National Research Council, 1983).

As a rule the catalytic potential of known bacterial selenoenzymes is not paralleled by mammalian selenoproteins and vice versa, selenophosphate synthetase being the only known exception. Our fragmentary knowledge does not, however, exclude the possibility that the highly complex catalytic centers comprising selenocysteine, pterine cofactor-bound molybdenum and flavin or selenocysteine-coordinated iron/nickel/sulfur clusters are not used in eukaryotes. New sequences of mammalian selenoproteins are being detected at high speed by 'in silico cloning' (Lescure et al., 1999; Kryukov et al., 1999), and pulse-label experiments with radioactive selenium suggest the existence of another dozen or two, giving ample room for further surprises when the catalytic potentials and structures of these proteins emerge. It can also not be taken for granted that selenium exerts its catalytic role in mammals exclusively as a selenocysteine residue that is integrated into proteins. The chemical nature of the 'acidvolatile selenium' (Diplock et al., 1973) of rat liver has never been worked out. Certainly, $\mathrm{H}_{2} \mathrm{Se}$ eventually could be generated from acid-denatured selenocysteine-containing proteins by $\beta$-elimination, but liberation of $\mathrm{H}_{2} \mathrm{Se}$ by acid from a selanyl-bond, as present in bacterial $\mathrm{CO}$ dehydrogenase, or from iron/selenide clusters, must be rated as more likely.

As to the medical implications of selenium research, we may safely state that severe selenium deficiency requires supplementation, as is suggested from the eradication of Keshan disease in supplemented areas in China and the prevention of analogous symptoms in patients on supplemented parenteral nutrition. As evident from the experiments with cGPx(-/-) mice, the cardiac complication in selenium deficiency likely results from a disturbed hydroperoxide metabolism. Evidence is also emerging that selenium deficiency specifically complicates iodine deficiency by increasing the oxidative challenge to the thyroid. In all other pathological conditions for which selenium supplementation is currently discussed, neither a satisfying rationale nor compelling clinical data are available. Nevertheless, the beneficial effects of selenium inferred from softer data, e. g. epidemiological surveys on cancer incidence and cardiovascular disease, small-scale clinical trials with critically ill patients, the unexpected accidental observations in large-scale cancer prevention trials, or veterinary experience with selenium responsiveness of inflammatory diseases, should not be ignored. They certainly demand validation by dedicated prospective studies. In chronically developing multifactorial diseases like oncogenesis and cardiovascular disease such trials are hard to design, if they are feasible at all. Rather, these problems may be rationally approached by studying the potential relevance of individual selenoproteins and their dependency on the selenium status. Thereby, selenium-responsive disease-related surrogate endpoints could be defined, which then may be tested in short-term clinical trials with manageable sample sizes.

\section{Acknowledgements}

This review has been compiled from some state-of-the-art reviews of the applications for a priority research program that was granted by the Deutsche Forschungsgemeinschaft in summer 1999. The secretarial help of B. Schinner-Schäfer and B. Steinert is gratefully acknowledged.

\section{References}

Adham, I.M., Tessmann, D., Soliman, K.A., Murphy, D., Kremling, H., Szpirer, C., and Engel, W. (1996). Cloning, expression, and chromosomal localization of the rat mitochondrial capsule selenoprotein gene (MCS): the reading frame does not contain potential UGA selenocysteine codons. DNA Cell. Biol. 15, $159-166$.

Andreesen, J .R., and Ljungdahl, L. (1973). Formate dehydrogenase of Clostridium thermoaceticum: incorporation of selenium-75, and the effect of selenite, molybdate and tungstate on the enzyme. J . Bacteriol. 116, 867-873.

Andreesen, J . R., Wagner, M., Sonntag, D., Kohlstock, M., Harms, C., Gursinsky, T., J äger, J ., Parther, T., Kabisch, U., Gräntzdörffer, A., Pich, A., and Söhling, B. (1999). Various functions of selenols and thiols in anaerobic gram-positive, amino acidutilizing bacteria. BioFactors 10, 263-270.

Angstwurm, M.W.A., Schottdorf, J ., Schopohl, J ., and Gärtner, R. (1999). Selenium replacement in patients with severe systemic inflammatory response syndrome improves clinical outcome. Crit. Care Med. 27, 1807 - 1813.

Arkowitz, R.A., and Abeles, R.H. (1990). Isolation and characterization of a covalent selenocysteine intermediate in the glycine reductase system. J . Am. Chem. Soc. 112, 870- 872.

Arteel, G.E., Mostert, V., Oubrahim, H., Briviba, K., Abel, J ., and Sies, H. (1998). Protection by selenoprotein $P$ in human plasma against peroxynitrite-mediated oxidation and nitration. Biol. Chem. 379, $1201-1205$.

Arteel, G.E., Briviba, K., and Sies, H. (1999). Protection against peroxinitrite. FEBS Lett. 445, 226- 230.

Arteel, G.E., Franken, S., Kappler, J ., and Sies, H. (2000). Binding of selenoprotein $\mathrm{P}$ to heparin: characterization with surface plasmon resonance. Biol. Chem. 381, 265- 268.

Arthur, J .R., Nicol, F., and Beckett, G.J . (1990). Hepatic iodothyronine $5^{\prime}$-deiodinase. The role of selenium. Biochem. J . 272, $537-540$.

Aumann, K.-D., Bedorf, N., Brigelius-Flohé, R., Schomburg, D., and Flohé, L. (1997). Glutathione peroxidase revisited. Simulation of the catalytic cycle by computer-assisted molecular modelling. Biomed. Environ. Sci. 10, 136- 155.

Bähr, K., Dreher, I., and Köhrle, J . (1999). Selenium supplementation by selenium yeast and sodium selenite: analysis of the selenium status as well as risks of deficiency and intoxication. J . Lab. Med. 23, 594- 599.

Baron, C., Heider, J., and Böck, A. (1993). Interaction of translation factor SELB with the formate dehydrogenase $\mathrm{H}$ 
selenopolypeptide mRNA. Proc. Natl. Acad. Sci. USA 90, $4181-4185$.

Beck, M.A., Esworthy, R.S., Ho, Y.S., and Chu, F.F. (1998). Glutathione peroxidase protects mice from viral-induced myocarditits. FASEB J . 12, 1143-1149.

Behne, D., Kyriakopoulos, A., M einhold, H., and Köhrle, J . (1990). Identification of type I iodothyronine 5 '-deiodinase as a selenoenzyme. Biochem. Biophys. Res. Commun. 173, 1143- 1149.

Behne, D., Kyriakopoulos, A., Weiss-Nowak, C., Kalckloesch, W.C., and Gessner, H. (1996). Newly found selenium-containing proteins in the tissues of the rat. Biol. Trace Elem. Res. 55, $99-110$.

Behne, D., Kyriakopoulos, A., Kalckloesch, M., Weiss-Nowak, C., Pfeifer, H., Gessner, H., and Hammel, C. (1997). Two new selenoproteins found in the prostatic glandular epithelium and in the spermatid nuclei. Biomed. Environ. Sci. 10, 340 - 345.

Berry, M.J ., Banu, L., Chen, Y.Y., Mandel, S.J ., Kieffer, J .D., Harney, J.W., and Larsen, P.R. (1991). Recognition of UGA as a selenocysteine codon in type I deiodinase requires sequences in the 3' untranslated region. Nature 353, 273- 276.

Berry, M.J ., Banu, L., Harney, J .W., and Larsen, P.R. (1993). Functional characterization of the eukaryotic SECIS elements which directs selenocysteine insertion at UGA codons. EMBO J . 12, $3315-3322$.

Björnstedt, M., Kumar, S., and Holmgren, A. (1995). Selenite and selenodiglutathione: reactions with thioredoxin systems. Meth. Enzymol. 252, 209- 219.

Björnstedt, M., Kumar, S., Björkhem, L., Spyrou, G., and Holmgren, A. (1997). Selenium and the thioredoxin and glutaredoxin systems. Biomed. Environ. Sci. 10, $271-279$.

Böck, A. (2000). Biosynthesis of selenoproteins - an overview. BioFactors 11, $77-78$.

Böck, A., and Stadtman, T.C. (1988). Selenocysteine, a highly specific component of certain enzymes, is incorporated by a UGA directed co-translational mechanism. BioFactors 1 , $245-250$.

Böck, A., Forchhammer, K., Heider, J ., and Baron, C. (1991a). Selenoprotein synthesis: an expansion of the genetic code. Trends Biochem. Sci. 16, 463- 467.

Böck, A., Forchhammer, K., Heider, J ., Leinfelder, W., Sawers, G., Veprek, B., and Zinoni, F. (1991b). Selenocysteine: the 21st amino acid. Mol. Microbiol. 5, 515- 520.

Bösl, M.R., Takaku, K., Oshima, M., Nishimura, S., and Taketo, M.M. (1997). Early embryonic lethality caused by targeted disruption of the mouse selenocysteine tRNA gene (Trsp). Proc. Natl. Acad. Sci. USA 94, 5531- 5534.

Boyington, J.C., Gladyshev, V.N., Khangulov, S.V., Stadtman, T.C., and Sun, P.D. (1997). Crystal structure of formate dehydrogenase $\mathrm{H}$ : catalysis involving $\mathrm{Mo}$, molybdopterin, selenocysteine, and an Fe4S 4 cluster. Science 275, 1305 - 1308.

Brigelius-Flohé, R. (1999). Tissue-specific functions of individual glutathione peroxidases. Free Rad. Biol. Med. 27, 951 - 965.

Brigelius-Flohé, R., Aumann, K.D., Blöcker, H., Gross, G., Kiess, M., Klöppel, K.-D., Maiorino, M., Roveri, A., Schuckelt, R., Ursini, F., Wingender, E., and Flohé, L. (1994). Phospholipid hydroperoxide glutathione peroxidase. J. Biol. Chem. 269, $7342-7348$.

Brigelius-Flohé, R., Friedrichs, B., Maurer, S., Schultz, M., and Streicher, R. (1997). Interleukin-1-induced nuclear factor kB activation is inhibited by overexpression of phospholipid hydroperoxide glutathione peroxidase in a human endothelial cell line. Biochem. J . 328, 199- 203.

Burk, R.F., and Hill, K.E. (1993). Regulation of selenoproteins. Annu. Rev. Nutr. 13, 65-81.

Burk, R.F., and Hill, K.E. (1994). Selenoprotein P. A selenium-rich extracellular glycoprotein. J . Nutr. 124, 1891 - 1897.
Calvin, H.I., Cooper, G.W., and Wallace, E. (1981). Evidence that selenium in rat sperm is associated with cysteine-rich structural protein of the mitochondrial capsules. Gam. Res. 4, $139-149$.

Cataldo, L., Baig, K., Oko, R., Mastrangelo, M.-A., and Kleene, K.C. (1996). Developmental expression, intracellular localization, and selenium content of the cysteine-rich protein associated with the mitochondrial capsules of mouse sperm. Mol. Reprod. Dev. 45, 320 - 331.

Chambers, I., Frampton, J ., Goldfarb, P., Affara, N., McBain, W., and Harrison, P.R. (1986). The structure of the mouse glutathione peroxidase gene: the selenocysteine in the active site is encoded by the 'termination' codon, TGA. EMBO J . 5, 1221 1227.

Cheng, W.H., Ho, Y.-S., Valentine, B.A., Ross, D.A., Combs, G.F., and Lei, X.G. (1998). Cellular glutathione peroxidase is the mediator of body selenium to protect against paraquat lethality in transgenic mice. J . Nutr. 128, 1070-1076.

Chu, F.F., Doroshow, J .H., and Esworthy, R.S. (1993). Expression, characterization, and tissue distribution of a new cellular selenium-dependent glutathione peroxidase, GSHPx-GI. J . Biol. Chem. 268, 2571-2576.

Clark, L.C., Combs, G.F., Turnbull, B.W., Slate, E.H., Chalker, D.K., Chow, J ., Davis, L.S., Glover, R.A., Graham, G.F., Gross, E.G., Krongrad, A., Lesher, J .L., Park, H.K., Sanders, B.B., Smith, C.L., and Taylor, J .R. (1996). Effects of selenium supplementation for cancer prevention in patients with carcinoma of the skin. J AM A 276, 1957- 1963.

Cody, V., Köhrle, J ., Auf'mkolk, M., and Hesch, R.D. (1986). Structure-activity relationships of flavonoid deiodinase inhibitors and enzyme active-site models. In: Plant flavonoids in biology and medicine: Biochemical, pharmacological and structureactivity relationships, V. Cody, E. Middleton, J r., and J .B. Harborne, eds. (New York, USA: Alan R. Liss, Inc.), pp. 373- 382.

Combs, G.F., Clark, L.C., and Turnbull, B.W. (1997). Reduction of cancer risk with an oral supplement of selenium. Biomed. Environ. Sci. 10, $227-234$.

Combs, G.F., and Gray, W.P. (1998). Chemopreventive agents: Selenium. Pharmacol. Ther. 79, 179- 192.

Cone, J .E., Del Rio, R.M., Davis, J.N., and Stadtman, T.C. (1976). Chemical characterization of the selenoprotein component of clostridial glycine reductase: identification of selenocysteine as the organoselenium moiety. Proc. Natl. Acad. Sci. USA 73, $2659-2663$.

Contempre, B., Denef, J .F., Dumont, J .E., and Many, M.C. (1993). Selenium deficiency aggravates the necrotizing effects of a high iodide dose in iodine deficient rats. Endocrinology 132, 1866 - 1868.

Contempre, B., Le Moine, O., Dumont, J.E., Denef, J .-F., and Many, M.C. (1996). Selenium deficiency and thyroid fibrosis. A key role for macrophages and transforming growth factor (TGF- $\beta$ ). Mol. Cell. Endocrinol. 124, 7- 15.

Copeland, P.R., Fletcher, J .E., Carlson, B.A., Hatfield, D.L., and Driscoll, D.M. (2000). A novel RNA binding protein, SBP2, is required for the translation of mammalian selenoprotein mRNAs. EMBO J . 19, 306-314.

Cowan, D.B., Weisel, R.D., Williams, W.G., and Mickle, D.A.G. (1993). Identification of oxygen responsive elements in the 5 '-flanking region of the human glutathione peroxidase gene. J . Biol. Chem. 268, 26904-26910.

Croteau, W., Whittemore, S.K., Schneider, M.J ., and Germain, D. L. (1995). Cloning and expression of a cDNA for a mammalian type III iodothyronine deiodinase. J . Biol. Chem. 270, 1656916575.

Davey, J .C., Becker, K.B., Schneider, M.J ., Germain, G.L., and Galton, V.A. (1995). Cloning of a cDNA for the type II iodothy- 
roine deiodinase. J . Biol. Chem. 270, 26786- 26789

Dimitrov, N.V., Charamella, L.J ., M eer, C.J ., Strowe, H.D., Ku, P.K., and Ulley, D.E. (1986). Modulation of natural killer cell activity by selenium in humans. J . Nutr. Growth Cancer 3, $193-198$.

Diplock, A.T., Caygill, C.P.J ., J effrey, E.H., and Thomas, C. (1973). The nature of the acid-volatile selenium in the liver of the male rat. Biochem. J . 134, 283.

Dobbek, H., Gremer, L., Meyer, O., and Huber, R. (1999). Crystal structure and mechanism of $\mathrm{CO}$ dehydrogenase, a molybdo iron-sulfur flavoprotein containing S-selanylcysteine. Proc. Natl. Acad. Sci. USA 96, 8884 - 8889.

Dreher, I., J akobs, T.C., and Köhrle, J . (1997). Cloning and characterization of the human selenoprotein $\mathrm{P}$ promotor: response of selenoprotein P expression to cytokines in liver cells. J . Biol. Chem. 272, 29364- 29371.

Dumont, J .E., Corvilain, B., and Contempre, B. (1994). The biochemistry of endemic cretinism: roles of iodine and selenium deficiency and goitrogens. Mol. Cell. Endocrinol. 100, $163-$ 166.

Epp, O., Ladenstein, R., and Wendel, A. (1983). The refined structure of the selenoenzyme glutathione peroxidase at $0.2-\mathrm{nm}$ resolution. Eur. J. Biochem. 133, $51-69$.

Flohé, L. (1989). The selenoprotein glutathione peroxidase. In: Glutathione: Chemical, biochemical, and medical aspects, D. Dolphin, R. Poulson, and O. Avramovic, eds. (New York, USA: J ohn Wiley and Sons, Inc.), pp. 644 - 731.

Flohé, L., Günzler, W., and Schock, H.H. (1973). Glutathione peroxidase: a selenoenzyme. FEBS Lett. 32, 132 - 134

Flohé, L., Wingender, E., and Brigelius-Flohé, R. (1997). Regulation of Glutathione Peroxidases. In: Oxidative Stress and Signal Transduction, H.J . Forman and E.Cadenas, eds. (New York, USA: Chapman and Hall), pp. 415 - 440.

Flohé, L., Hecht, H.J ., and Steinert, P. (1999). Glutathione and trypanothione in parasitic hydroperoxide metabolism. Free Rad. Biol. Med. 27, 966 - 984.

Flohé, L., Andreesen, J .R., Brigelius-Flohé, R., Maiorino, M., and Ursini, F. (2000). Selenium, the element of the moon in life on earth. IUBMB Life, in press.

Follmann, H., and Häberlein, I. (1995). Thioredoxins: universal, yet specific thiol-disulfide redox cofactors. BioFactors 5, 147 156.

Forceville, X., Vitoux, D., Gauzit, R., Combes, A., Lahilaire, P., and Chappuis, P. (1998). Selenium, systemic immune response syndrome, sepsis, and outcome in critically ill patients. Crit. Care Med. 26, 1536- 1544.

Forchhammer, K., Boesmiller, K., and Böck, A. (1991). The function of selenocysteine synthase and SELB in the synthesis and incorporation of selenocysteine. Biochimie 73, 1481 - 1486.

Forstrom, J .W., Hachowski, J J ., and Tappel, A.L. (1978). Identification of the catalytic site of rat liver glutathione peroxidase as selenocysteine. Biochemistry 17, 2639- 2644.

Friedrichs, B., Toborek, M., Hennig, B., Heinevetter, L., Müller, C., and Brigelius-Flohé, R. (1999). 13-HPODE and 13-HODE modulate cytokine-induced expression of end othelial cell adhesion molecules differently. BioFactors 9, 61-72.

Fu, Y., Cheng, W.-H., Porres, J .M., Ross, D.A., and Lei, X.G. (1999). Knockout of cellular glutathione peroxidase gene renders mice susceptible to diquat-induced oxidative stress. Free Rad. Biol. Med. 27, 605-611.

Ganther, H.E. (1999). Selenium metabolism, selenoproteins and mechanisms of cancer prevention: complexities with thioredoxin reductase. Carcinogenesis 20, 1657 - 1666.

Garbisu, C., Gonzalez, S., Yang, W.H., Yee, B.C., Carlson, D.L., Yee, A., Smith, N.R., Otero, R., Buchanan, B.B., and Leighton, T. (1995). Physiological mechanisms regulating the conversion of selenite to elemental selenium by Bacillus subtilis. BioFactors 5, 29-37.

Garcin, E., Vernede, X., Hatchikian, E. C., Volbeda, A., Frey, M., and Fontecilla-Camps, J. C. (1999). The crystal structure of a reduced [NiFeSe] hydrogenase provides an image of the activated catalytic center. Structure 7, 557- 566.

Gärtner, R., Angstwurm, M.W., and Schottdorf, J . (1997). Selenium administration in sepsis patients. Med. Klin. 92, 12-14.

Gasdaska, P.Y., Berggren, M.M., Berry, M.L., and Powis, G. (1999). Cloning, sequencing and functional expression of a novel human thioredoxin reductase. FEBS Lett. 442, 105 - 111.

Ge, K., and Yang, G. (1993). The epidemiology of selenium deficiency in the etiological study of endemic diseases in China. Am. J . Clin. Nutr. (Suppl.) 57, 259- 263.

Gladyshev, V.N., Khangulov, S.V., and Stadtman, T.C. (1996). Properties of the selenium- and molybdenum-containing nicotinic acid hydrolase from Clostridium barkeri. Biochemistry 35 , $212-223$.

Gladyshev, V.N., J eang, K.-T., Wootton, J .C., and Hatfield, D.L. (1998). A new human selenium-containing protein. J. Biol. Chem. 273, 8910-8915.

Glattre, E., Thomassen, Y., Thoresen, S.O., Haldorsen, T., LundLarsen, P.G., Theodorsen, L., and Aaseth, J. (1989). Prediagnostic serum selenium in a case-control study of thyroid cancer. Int. J . Epidemiol. 18, $45-49$.

Gorlatov, S.N., and Stadtman, T.C. (2000). The penultimate selenocysteine residue at the $\mathrm{C}$-terminus of mammalian thioredoxin reductase plays an obligatory role in the NADPH-disulfide oxidoreductase catalytic mechanism. BioFactors 11, $79-81$.

Gromer, S., Wissing, J ., Behne, D., Ashman, K., Schirmer, R.H., Flohé, L., and Becker, K. (1998). A hypothesis on the catalytic mechanism of the selenoenzyme thioredoxin reductase. Biochem. J . 332, 591-592.

Gross, M., Oertel, M., and Köhrle, J . (1995). Differential selenium-dependent expression of type I 5 '-deiodinase and glutathione peroxidase in the porcine epithelial kidney cell line LLC-PK1. Biochem. J . 306, 851-856.

Guimaraes, M.J ., Peterson, D., Vicari, A., Cocks, B.G., Copeland, N.G., Gilbert, D.J ., J enkins, N.A., Ferrick, D.A., Kastelein, R.A., Bazan, J .F., and Zlotnik, A. (1996). Identification of a novel selD homolog from eukaryotes, bacteria, and archeae: is there an autoregulatory mechanism in selenocysteine metabolism? Proc. Natl. Acad. Sci. USA 93, 15086 - 15091.

Günzler, W.A., Steffens, G.J ., Grossmann, A., Kim, S.M., Ötting, F., Wendel, A., and Flohé, L. (1984). The amino-acid sequence of bovine glutathione peroxidase. Hoppe-Seyler's Z. Physiol. Chem. 353, 195- 212.

Haan, J .B. de, Bladier, C., Griffiths, P., Kelner, M., O'Shea, R.D., Cheung, N.S., Bronson, R.T., Silvestro, M.J ., Wild, S., Zheng, S.S., Beart, P.M., Hertzog, P.J ., and Kola, I. (1998). Mice with a homozygous null mutation for the most abundant glutathione peroxidase, GPx1, show increased susceptibility to the oxidative stress-inducing agents paraquat and hydrogen peroxide. J . Biol. Chem. 273, 22528-22536.

Haring, D., and Schreier, P. (1999). Chemical engineering of enzymes: altered catalytic activity, predictable selectivity and exceptional stability of the semisynthetic peroxidase selenosubtilisin. Naturwissenschaften $86,307-312$.

Haurand, M., and Flohé, L. (1988). Kinetic studies on arachidonate 5-lipoxygenase from rat basophilic leukemia cells. Biol. Chem. Hoppe-Seyler 369, 133-142.

Hawker, F.H., Stewart, P.M., and Snitch, P.J . (1990). Effects of acute illness on selenium homeostasis. Crit. Care Med. 18, $442-446$ 
Hayashi, T., Ueno, Y., and Okamoto, T. (1993). Oxidoreductive regulation of nuclear factor kappa $B$. Involvement of a cellular reducing catalyst thioredoxin. J . Biol. Chem. 268, 11380-11388.

Hentze, M.W. (1991). Determinants and regulation of cytoplasmic mRNA stability in eukaryotic cells. Biochim. Biophys. Acta 1090, $281-292$.

Hill, K.E., and Burk, R.F. (1997). Selenoprotein P: Recent studies in rats in humans. Biomed. Environ. Sci. 10, 198- 208.

Ho, Y.-S., Magnenat, J .-L., Bronson, R.T., Cao, J ., Gargano, M., Sugawara, M., and Funk, C.D. (1997). Mice deficient in cellular glutathione peroxidase develop normally and show no increased sensitivity to hyperoxia. J. Biol. Chem. 272, 16644 16651.

Holmgren, A. (2000). Redox regulation by thioredoxin and thioredoxin reductase. BioFactors $11,63-64$.

Holmgren, A., and Björnstedt, M. (1995). Thioredoxin and thioredoxin reductase. Meth. Enzymol. 252, 199- 208.

Hubert, N., Walczak, R., Carbon, P., and Krol, A. (1996). A protein binds the selenocysteine insertion element in the $3^{\prime}$-UTR of mammalian selenoprotein mRNAs. Nucleic Acids Res. 24, $464-469$.

Imai, H., Narashima, K., Arai, M., Sakamoto, H., Chiba, N., and Nakagawa, Y. (1998). Suppression of leukotriene formation in RBL-2H3 cells that overexpressed phospholipid hydroperoxide glutathione peroxidase. J . Biol. Chem. 273, 1990- 1997.

Ip, C. (1998). Lessons from basic research in selenium and cancer prevention. J . Nutr. 128, $1845-1854$.

Ip, C., and Ganther, H.E. (1990). Activity of methylated forms of selenium in cancer prevention. Cancer Res. 50, $1206-1211$.

J aeschke, H., Ho, Y.-S., Fisher, M.A., Lawson, J .A., and Farhood, A. (1999). Glutathione peroxidase-deficient mice are more susceptible to neutrophil-mediated hepatic parenchymal cell injury during endotoxemia: importance of an intracellular oxidant stress. Hepatology 29, 443-450.

J akobs, T., Schmutzler, C., Meissner, J ., and Köhrle, J . (1997). The promotor of the human type I 5 '-deiodinase gene: mapping of the transcription start site and identification of a $D R+4$ thyroid hormone responsive element. Eur. J. Biochem. 247, 288 - 297.

J ones, J .B., Dilworth, G.L., and Stadtman, T.C. (1979). Occurrence of selenocysteine in the selenium-dependent formate dehydrogenase of Methanococcus vannielli. Arch. Biochem. Biophys. 195, 255- 260.

Kabisch, U.C., Gräntzdörffer, A., Schierhorn, A., Rücknagel, K.P., Andreesen, J .R., and Pich, A. (1999). Identification of D-proline reductase from Clostridium sticklandii as a selenoenzyme and indications for a catalytically active pyruvoyl group derived from a cysteine residue by cleavage of a proprotein. J. Biol. Chem. 274, 8445-8454.

Knekt, P., Marniemi, J ., Teppo, L., Heliovaara, M., and Aromaa, A. (1998). Is low selenium status a risk factor for lung cancer? Am. J. Epidemiol. 148, 975 - 982.

Köhrle, J . (1999a). The trace element selenium and the thyroid gland. Biochimie 81, 527- 533.

Köhrle, J . (1999b). Local activation and inactivation of thyroid hormones: the deiodinase family. Mol. Cell. Endocrinol. 151, $103-119$.

Köhrle, J . (2000a). The selenoenzyme family of deiodinase isoenzymes controls local thyroid hormone availability. Rev. Endocrine Metabol. Dis. 1, 49-58.

Köhrle, J . (2000b). The deiodinase family - selenoenzymes regulating thyroid hormone availability and action. Cell. Mol. Life Sci., in press.

Kreimer, S., and Andreesen, J .R. (1995). Glycine reductase of Clostridium litorale. Cloning, sequencing, and molecular analysis of the grdAB operon that contains two in-frame TGA codons for selenium incorporation. Eur. J . Biochem. 234, 192 - 199.
Kretz-Remy, C., Mehlen, P., Mirault, M.E., and Arrigo, A.P. (1996). Inhibition of I kappa B-alpha phosphorylation and degradation and subsequent NF-kappa B activation by glutathione peroxidase overexpression. J. Cell Biol. 133, 1083- 1093

Kryukov, G.V., Kryukov, V.M., and Gladyshev, V.N. (1999). New mammalian selenocysteine-containing proteins identified with an algorithm that searches for selenocysteine insertion sequence elements. J. Biol. Chem. 274, 33888 - 33897.

Lacourciere, G.M. (1999). Biosynthesis of selenophosphate. BioFactors 10, $237-244$

Lacourciere, G.M., and Stadtman, T.C. (1999). Catalytic properties of selenophosphate synthetases: comparison of the selenocysteine-containing enzyme from Haemophilus influenzae with the corresponding cysteine-containing enzyme from Escherichia coli. Proc. Natl. Acad. Sci. USA 96, 44 - 48.

Läuchli, A. (1993). Selenium in plants: uptake, functions, and environmental toxicity. Bot. Acta 106, $455-468$.

Lee, B.J ., Worland, P.J ., Davis, J .N., Stadtman, T.C., and Hatfield, D.L. (1989). Identification of a selenocysteyl-tRNA-Ser in mammalian cells that recognizes the nonsense codon UGA. J. Biol. Chem. 264, 9724 - 9727.

Lee, S.R., Kim, J R., Kwon, K.S., Yoon, H.W., Levine, R.L., Ginsburg, A., and Rhee, S.G. (1999). Molecular cloning and characterization of a mitochondrial selenocysteine-containing thioredoxin reductase from rat liver. J. Biol. Chem. 274, 4722 - 4734.

Lee, S.R., Bar-Noy, S., Kwon, J ., Levine, R.L., Stadtman, T.C., and Rhee, S.G. (2000). Mammalian thioredoxin reductase: Oxidation of the C-terminal cysteine/selenocysteine active site forms a thioselenide, and replacement of selenium with sulfur markedly reduces catalytic activity. Proc. Natl. Acad. Sci. USA 97, $2521-2526$.

Lei, X.G., Evenson, J.K., Thompson, K.M., and Sunde, R.A. (1995). Glutathione peroxidase and phospholipid hydroperoxide glutathione peroxidase are differentially regulated in rats by dietary selenium. J . Nutr. 125, $1438-1446$.

Leinfelder, W., Forchhammer, K., Zinoni, F., Sawers, G., Mandrand-Berthelot, M.-A., and Böck, A. (1988). Escherichia coli genes whose products are involved in selenium metabolism. J. Bacteriol. 170, 540-546.

Leinfelder, W., Forchhammer, K., Veprek, B., Zehelein, E., and Böck, A. (1990). In vitro synthesis of selenocysteinyl-tRNA $A_{U C A}$ involvement and characterization of the selD gene product. Proc. Natl. Acad. Sci. USA 87, 543- 547.

Lescure, A., Gautheret, D., Carbon, P., and Krol, A. (1999). Novel selenoproteins identified in silico and in vivo by using a conserved RNA structural motif. J. Biol. Chem. 274, $38147-$ 38154.

Lesoon, A., Mehta, A., Singh, R., Chisolm, G.M., and Driscoll, D.M. (1997). An RNA-binding protein recognizes a mammalian selenocysteine insertion sequence element required for cotranslational incorporation of selenocysteine. Mol. Cell. Biol. 17, $1977-1985$.

Low, S.C., and Berry, M.J . (1996). Knowing when not to stop: selenocysteine incorporation in eukaryotes. Trends Biochem. Sci. 21, 203- 208.

Low, S.C., Harney, J .W., and Berry, M.J . (1995). Cloning and functional characterization of human selenophosphate synthetase, an essential component of selenoprotein synthesis. J. Biol. Chem. 270, 21659-21664.

Maiorino, M., Aumann, K.-D., Brigelius-Flohé, R., Doria, D., van den Heuvel, J ., McC arthy, J ., Roveri, A., Ursini, F., and Flohé, L. (1995). Probing the presumed catalytic triad of selenium-containing peroxidases by mutational analysis of phospholipid hydroperoxide glutathione peroxidase (PHGPX). Biol. Chem. Hoppe-Seyler 376, 651-660. 
Maiorino, M., Roche, C., Kiess, M., Koenig, K., Gawlik, D., Matthes, M., Naldini, E., Pierce, R., and Flohé, L. (1996). A selenium-containing phospholipid-hydroperoxide glutathione peroxidase in Schistosoma mansoni. Eur. J. Biochem. 238, 838-844.

Maiorino, M., Wissing, J.B., Brigelius-Flohé, R., Calabrese, F., Roveri, A., Steinert, P., Ursini, F., and Flohé, L. (1998). Testosterone mediates expression of the selenoprotein PHGPx by induction of spermatogenesis and not by direct transcriptional gene activation. FASEB J . 12, 1359- 1370.

Maiorino, M., Flohé, L., Roveri, A., Steinert, P., Wissing, J .B., and Ursini, F. (1999). Selenium and reproduction. BioFactors 10, $251-256$.

Makino, Y., Yoshikawa, N., Okamoto, K., Hirota, K., Yodoi, J ., Makino, I., and Tanaka, H. (1999). Direct association with thioredoxin allows redox regulation of glucocorticoid receptor function. J . Biol. Chem. 274, 3182 - 3188.

Marcocci, L., Flohé, L., and Packer, L. (1997). Evidence for a functional relevance of the selenocysteine residue in mammalian thioredoxin reductase. BioFactors 6, 351- 358 .

Matsui, M., Oshima, M., Oshima, H., Takaku, K., Maruyama, T., Yodoi, J ., and Taketo, M.M. (1996). Early embryonic lethality caused by targeted disruption of the mouse thioredoxin gene. Dev. Biol. 178, 179- 185.

Mc Kenzie, R.C., Rafferty, T.S., and Beckett, G.J . (1998). Selenium: an essential element for immune function. Immunol. Today $19,342-345$.

Mills, G.C. (1957). Hemoglobin catabolism. I. Glutathione peroxidase, an erythrocyte enzyme which protects hemoglobin from oxidative breakdown. J . Biol. Chem. 229, 189 - 197.

Miranda-Vizuete, A., Damdimopoulos, A.E., Pedrajas, J.R., Gustafsson, J.-A.., and Spyrou, G. (1999). Human mitochondrial thioredoxin reductase. Eur. J . Biochem. 261, 405- 412.

Mizuno, K., Hirata, S., Hoshi, K., Shinohara, A., and Chiba, M. (2000). Analysis of the phospholipid hydroperoxide glutathione peroxidase mRNA in the rat spermatozoon and effect of selenium deficiency on the mRNA. Biol. Trace Elem. Res. 74, $71-79$.

Moreno-Reyes, R., Suetens, C., Mathieu, F., Begaux, F., Zhu, D., Rivera, M.T., Boelart, M., Nève, J ., Perlmutter, N., and Vanderpas, J. (1998). Kashin-Beck osteoarthropathy in rural Tibet in relation to selenium and iodine status. New England J. Med. 339, $1112-1120$.

Mörk, H., Lex, B., Scheurlen, M., Dreher, I., Schütze, N., Köhrle, J ., and J akob, F. (1998). Expression pattern of gastrointestinal selenoproteins. Nutr. Cancer 32, $64-70$.

Mostert, V., Dreher, I., Köhrle, J ., and Abel, J . (1999). Transforming growth factor $\beta 1$ inhibits expression of selenoprotein $P$ in cultured human liver cells. FEBS Lett. 460, 23-26.

Motsenbocker, M.A., and Tappel, A.L. (1984). Effect of dietary selenium on plasma selenoprotein $\mathrm{P}$, selenoprotein $\mathrm{P} 1$ and glutathione peroxidase in the rat. I. Nutr. 114, 279- 285.

Nasim, M.T., J aenecke, S., Belduz, A., Kollmus, H., Flohé, L., and McCarthy, J .E.G. (2000). Eukaryotic selenocysteine incorporation follows a non-processive mechanism that competes with translational termination. J. Biol. Chem. 275, 14846- 14852.

National Research Council (U.S.), Subcommittee on Selenium, Committee on Animal Nutrition, Board on Agriculture (1983). Selenium in Nutrition (Washington D.C., USA: Natl. Acad. Press).

Neuhierl, B., Thanbichler, M., Lottspeich, F., and Bock, A. (1999). A family of $\mathrm{S}$-methylmethionine-dependent thiol/selenol methyltransferases. Role in selenium tolerance and evolutionary relation. J. Biol. Chem. 274, 5407- 5414.

Pallini, V., and Bacci, E. (1979). Bull sperm selenium is bound to a structural protein of mitochondria. J . Submicr. Cytol. 11, $165-170$.
Pfeiffer, M., Bingemann, R., and Klein, A. (1998). Fusion of two subunits does not impair the function of a (NiFeSe)-hydrogenase in the archaeon Methanococcus voltae. Eur. J . Biochem. $256,447-452$.

Pinsent, J . (1954). The need for selenite and molybdate in the formation of formic dehydrogenase by members of the Coli-aerogenes group of bacteria. Biochem. J . 57, 10 - 16.

Prabha, P.S., Das, U.N., Ramesh, G., Kumar, K.V., and Kamalakar, V. (1991). Free radical generation, lipid peroxidation and essential fatty acids in patients with septicemia. Prostaglandins Leukot. Essent. Fatty Acids 42, 61 - 65.

Rhee, S.G., Kang, S.W., Netto, L.E., Seo, M.S., and Stadtman, E.R. (2000). A family of novel peroxidases, peroxiredoxins. BioFactors 11, 207- 209.

Richard, M.J ., Arnaud, J ., J urkovitz, C., Hachache, T., M eftahi, H., Laporte, F., Foret, M., Favier, A., and Cordonnier, D. (1991). Trace elements and lipid peroxidation abnormalities in patients with chronic renal failure. Nephron 57, 10 - 15.

Ringstad, J ., Kildebo, S., and Thomassen, Y. (1993). Serum selenium, copper, and zinc concentrations in Crohn's disease and ulcerative colitis. Scand. J. Gastroenterol. 28, 605- 608.

Robinson, M.K., Rounds, J.D., Hong, R.W., J acobs, D.O., and Wilmore, D.W. (1992). Glutathione deficiency increases organ dysfunction after hemorrhagic shock. Surgery 112, 140 - 147.

Rocher, C., Lalanne, J .-L., and Chaudière, J . (1992). Purification and properties of a recombinant sulfur analog of purine selenium-glutathione peroxidase. Eur. J . Biochem. 205, 955 960.

Rother, M., Wilting, R., Commans, S., and Böck, A. (2000). Identification and characterisation of the selenocysteine-specific translation factor SelB from the archaeon Methanococcus jannaschii. J . Mol. Biol. 299, 351- 358.

Rotruck, J .T., Hoekstra, W.G., Pope, A.L., Ganther, H., Swanson, A., and Hafemann, D. (1972). Relationship of selenium to GSH peroxidase. Fed. Proc. 31, 691

Saijoh, K., Saito, N., Lee, M.J ., Fujii, M., Kobayashi, T., and Sumino, K. (1995). Molecular cloning of CDNA encoding a bovine selenoprotein $\mathrm{P}$ - like protein containing 12 selenocysteines and a (His-Pro) rich domain insertion, and its regional expression. Mol. Brain Res. 30, 301 - 311

Saito, Y., Hayashi, T., Tanaka, A., Watanabe, Y., Suzuki M., Saito, E., and Takahashi, K. (1999). Selenoprotein P in human plasma as an extracellular phospholipid hydroperoxide glutathione peroxidase - isolation and enzymatic characterization of human selenoprotein P. J . Biol. Chem. 274, 2866- 2871.

Salonen, J .T. (1987). Selenium in ischaemic heart disease. Int. J . Epidemiol. 16, $323-328$.

Sando, K., Hoki, M., Nezu, R., Takagi, Y., and Okada, A. (1992). Platelet glutathione peroxidase activity in long-term total parenteral nutrition with and without selenium supplementation. J . Parenter. Enteral Nutr. 16, 54- 58.

Schewe, C., Schewe, T., and Wendel, A. (1994). Strong inhibition of mammalian lipoxygenases by the antiinflammatory seleno-organic compound ebselen in the absence of glutathione. Biochem. Pharmacol. 48, 65- 74.

Schmidt, K.J ., Bayer, W., Schweizer, T., and Hewel, T. (1998). Selensubstitution - ein therapeutischer Ansatzpunkt bei Schilddrüsenerkrankungen. VitaMinSpur 13, 33 - 39.

Schmutzler, C., Brtko, J., Winzer, R., J akobs, T.C., MeissnerWeigl, J ., Simon, D., Goretzki, P.E., and Köhrle, J . (1998). Functional retinoid and thyroid hormone receptors in human thyroid carcinoma cell lines and tissues. Int. J. Cancer. 76, 368- 376.

Schnurr, K., Belkner, J ., Ursini, F., Schewe, T., and Kühn, H. (1996). The selenoenzyme phospholipid hydroperoxide glutathione peroxidase controls the activity of the 15-lipoxygenase with 
complex substrates and preserves the specificity of the oxygenation products. J. Biol. Chem. 271, 4653-4658.

Schräder, T., Rienhöfer, A., and Andreesen, J . R. (1999). Selenium-containing xanthine dehydrogenase from Eubacterium barkeri. Eur. J. Biochem. 264, 862 - 871.

Schuckelt, R., Brigelius-Flohe, R., Maiorino, M., Roveri, A., Reumkens, J., Strassburger, W., Ursini, F., Wolf, B., and Flohe, L. (1991). Phospholipid hydroperoxide glutathione peroxidase is a selenoenzyme distinct from the classical glutathione peroxidase as evident from cDNA and amino acid sequencing. Free Rad. Res. Commun. 14, 343-361.

Schütze, N., Bachthaler, M., Lechner, A., Köhrle, J ., and J akob, F. (1998a). Identification by differential display PCR of the selenoprotein thioredoxin reductase as a $1,25(\mathrm{OH})_{2}$-vitamin $D_{3-}$ responsive gene in human osteoblast - regulation by selenite. BioFactors 7, 299 - 310.

Schütze, N., Dreher, I., J akob, F., and Köhrle, J . (1998b). Neue menschliche Selenoproteine: Selenoprotein $\mathrm{P}$ und Thioredoxin-Reduktase. J . Lab. Med. 22, 539- 544.

Schwaab, V., Faure, J ., Dufaure, J .P., and Drevet, J R. (1998). GPX3: the plasma-type glutathione peroxidase is expressed under androgenic control in the mouse epididymis and vas deferens. Mol. Reprod. Dev. 51, 362 - 372.

Schwarz, K., and Foltz, C.M. (1957). Selenium as an integral part of factor 3 against dietary necrotic liver degeneration. J. Am. Chem. Soc. 79, $3292-3293$.

Shen, Q., Mc Quilkin, P.S., and Newburger, P.E. (1995). RNA-binding proteins that specifically recognize the selenocysteine insertion sequence of human cellular glutathione peroxidase mRNA. J . Biol. Chem. 270, 30448 - 30452.

Shen, Q., Wu, R., Leonard, J .L., and Newburger, P.E. (1998). Identification and molecular cloning of a human selenocysteine insertion sequence-binding protein. J. Biol. Chem. 273, 54435446.

Sies, H., Gerstenecker, C., Menzel, H., and Flohé, L. (1972). Oxidation in the NADP system and release of GSSG from hemoglobin-free perfused rat liver during peroxidatic oxidation of glutathione by hydroperoxides. FEBS Lett. 27, $171-175$.

Sies, H., Sharov, V.S., Klotz, L.O., and Briviba, K. (1997). Glutathione peroxidase protects against peroxynitrite-mediated oxidations. A new function for selenoproteins as peroxynitrite reductase. J . Biol. Chem. 272, $27812-27817$.

Smith, W.L., and Lands, W.E. (1972). Oxygenation of polyunsaturated fatty acids during prostaglandin biosynthesis by sheep vesicular gland. Biochemistry 11, $3276-3285$.

Stadtman, T.C. (1990). Selenium biochemistry. Annu. Rev. Biochem. 59, 111- 127.

Steinberg, D. (1997). Low density lipoprotein oxidation and its pathological significance. J. Biol. Chem. 272, 2096320966.

Steinert, P., Bächner, D., and Flohé, L. (1998). Analysis of the mouse selenoprotein P gene. Biol. Chem. 379, 683-691.

Sunde, R.A. (1994). Intracellular glutathione peroxidases - Structure, regulation and function. In: Selenium in Biology and Human Health. R.F. Burk, ed. (New York, USA: Springer), pp. $45-77$.

Sztajer, H., Gamain, B., Slomianny, C., and Flohé, L. (2000). Functional characterization of a glutathione peroxidase from Plasmodium falciparum. $5^{\text {th }}$ Symposium "Free Radicals in Biology and Medicine", Lodz 7 - 10 J une, 2000 (Abstract).

Takahashi, K., Avissar, N., Whitin, J ., and Cohen, H. (1987). Purification and characterization of human plasma glutathione peroxidase: a selenoglycoprotein distinct from the known cellular enzyme. Arch. Biochem. Biophys. 256, 677-686.

Tamura, T., and Stadtman, T.C. (1996). A new selenoprotein from human lung adenocarcinoma cells: purification, properties, and thioredoxin reductase activity. Proc. Natl. Acad. Sci. USA 93, 1006- 1011.

Turner, D.C., and Stadtman, T.C. (1973). Purification of protein components of the clostridial glycine reductase system and characterization of protein $A$ as a selenoprotein. Arch. Biochem. Biophys. 154, 366- 381.

Ursini, F., Maiorino, M., Valente, M., Ferri, L., and Gregolin, C. (1982). Purification from pig liver of a protein which protects liposomes and biomembranes from peroxidative degradation and exhibits glutathione peroxidase activity on phosphatidylcholine hydroperoxides. Biochim. Biophys. Acta 710, $197-211$.

Ursini, F., Maiorino, M., Brigelius-Flohé, R., Aumann, K.D., Roveri, A., Schomburg, D., and Flohé, L. (1995). Diversity of glutathione peroxidases. Meth. Enzymol. 252, 38 - 53.

Ursini, F., Heim, S., Kiess, M., Maiorino, M., Roveri, A., Wising, J ., and Flohé, L. (1999). Dual function of the selenoproteins PHGPx during sperm maturation. Science 285, 1393- 1396.

Vendeland, S.C., Beilstein, M.A., Yeh, J .Y., Ream, W., and Whanger, P.D. (1995). Rat skeletal muscle selenoprotein W: cDNA clone and mRNA modulation by dietary selenium. Proc. Natl. Acad. Sci. USA 92, 8749 - 8753.

Vorholt, J . A., Vaupel, M., and Thauer, R. K. (1997). A seleniumdependent and a selenium-independent formylmethanofuran dehydrogenase and their transcriptional regulation in the hyperthermophilic Methanopyrus kandleri. Mol. Microbiol. 23, $1033-1042$.

Wagner, M., Sonntag, D., Grimm, R., Pich, A., Eckerskorn, C., Söhling, B., and Andreesen, J.R. (1999). Substrate-specific selenoprotein $B$ of glycine reductase from Eubacterium acidaminophilum. Biochemical and molecular analysis. Eur. J. Biochem. 260, 38- 49.

Watabe, S., Makino, Y., Ogawa, K., Hiroi, T., Yamamoto, Y., and Takahashi, S.Y. (1999). Mitochondrial thioredoxin reductase in bovine adrenal cortex its purification, properties, nucleotide/amino acid sequences, and identification of selenocysteine. Eur. J . Biochem. 264, 74 - 84.

Weitzel, F., and Wendel, A. (1993). Selenoenzymes regulate the activity of leukocyte 5 -lipoxygenase via the peroxide tone. J. Biol. Chem. 268, 6288-6292.

Wendel, A., Kerner, B., and Graupe, K. (1978). The Selenium Moiety of Glutathione Peroxidase. Hoppe-Seyler's Z. Physiol. Chem. 359, 1035 - 1036.

Whanger, P.D., Vendeland, S.C., Gu, Q.-P., Beilstein, M.A., and Ream, L.W. (1997). Selenoprotein W cDNAs from five species of animals. Biomed. Environ. Sci. 10, 190 - 197.

Wilting, R., Schorling, S., Persson, B.C., and Böck, A. (1997). Selenoprotein synthesis in Archaea: identification of an mRNA element of Methanococcus jannaschii probably directing selenocysteine insertion. J. Mol. Biol. 266, 637-641.

Wingler, K., Böcher, M., Flohé, L., Kollmus, H., and BrigeliusFlohé, R. (1999). mRNA stability and selenocysteine insertion sequence efficiency rank gastrointestinal glutathione peroxidase high in the hierarchy of selenoproteins. Eur. J. Biochem. 259, $149-157$.

Wingler, K., and Brigelius-Flohé, R. (2000). Gastrointestinal glutathione peroxidase. BioFactors 10, $245-249$.

Yamada, K. (1995). A new translational elongation factor for selenocysteyl-tRNA in eukaryotes. FEBS Lett. 377, 313- 317.

Yamamoto, Y., and Takahashi, K. (1993). Glutathione peroxidase isolated from plasma reduces phospholipid hydroperoxides. Arch. Biochem. Biophys. 305, 541- 545.

Ylä-Herttuala, S., Rosenfeld, M.E., Parthasarathy, S., Sigal, E., Sarkioja, T., Witztum, J .L., and Steinberg, D. (1991). Gene expression in macrophage-rich human atherosclerotic lesions. 15-lipoxygenase and acetyl low density lipoprotein receptor 
messenger RNA colocalize with oxidation specific lipid-protein adducts. J . Clin. Invest. 87, 1146- 1152.

Yan, J ., and Barrett, J .N. (1998). Purification from bovine serum of a survival-promoting factor for cultured central neurons and its identification as selenoprotein-P. J . Neurosci. 18, 8682 8691.

Zimmermann, T., Albrecht, S., Kuhne, H., Vogelsang, U., Grutzmann, R., and Kopprasch, S. (1997). Selenium administration in patients with sepsis syndrome. A prospective randomized study. Med. Klin. 92, Suppl. 3, 3-4.

Zinoni, F., Birkmann, A., Stadtman, T.C., and Böck, A. (1986). Nucleotide sequence and expression of the selenocysteinecontaining polypeptide of formate dehydrogenase (formatehydrogen-lyase-linked) from Escherichia coli. Proc. Natl. Acad. Sci. USA 83, 4650 - 4654 